\title{
風・波を同時に受ける浮体橋の動的応答 に関する風洞内水槽実験
}

\author{
麓 興一郎 1 - 新里 英幸 $2 \cdot$ 宇都宮智昭 $3 \cdot$ 田中 洋 4 - 渡邊 英一 5 \\ 1正会員 独立行政法人土木研究所 構造物研究グループ（テ305-8516つくば市南原1-6） \\ E-mail:fumoto@pwri.go.jp \\ 2正会員 日立造船株式会社 技術研究所（干551-0022大阪市大正区船町2-2-11） \\ E-mail:niizato@hitachizosen.co.jp \\ 3 正会員 京都大学助教授 工学研究科社会基盤工学専攻（干615-8540京都市西京区京都大学桂） \\ E-mail:utsunomi@mbox.kudpc.kyoto-u.ac.jp \\ 4正会員 日立造船株式会社 (研究当時)（广559-8559大阪市住之江区南港北1-7-89） \\ E-mail:tanaka_hiroshi@dsk.zaq.ne.jp \\ 5フェロー 京都大学名誉教授 財団法人大阪地域計画研究所（干561-0834豊中市庄内栄町2-21-1） \\ E-mail: watanabe@rpi.or.jp
}

\begin{abstract}
大型風洞の風路に設置された造波水槽内に非線形係留された分離ポンツーン型の弾性浮体橋模型を浮か べ，風と波が各々単独に作用する場合と同時に作用する場合について実験を行い，浮体橋の動摇特性を調 べた。また，麓らが開発した浮体橋の動的挙動計算プログラムを用いて実験対応の計算を行い，その有効 性を調べた. その結果，1) 波周波数とポンツーンの動摇の固有振動数とが一致する場合, 浮体橋の応答は 卓越すること，2) 風の影響によって浮体橋は風下側に定常変位し，この変位した状態で動摇すること，3) 風と波を同時に受ける場合の桁の忘答ピークは, 波が単独で作用する場合よりも大きくなること, 4) 風洞 内水槽実験の波浪中弾性挙動は, 解析で得られた結果とほぼ一致し, 本稿で実施された実験手法は妥当な ものと判断されたこと，が明らかになった。
\end{abstract}

Key Words : floating bridge, elastic model, nonlinear mooring system, in winds and waves

\section{1. 緒 言}

浮体橋は，海中橋脚の設置が不要なため，従来型の橋 梁では架設困難な大水深域や軟弱地盤層の厚い地点にお いても架設可能で，海中橋脚を設置する固定橋と比較す ると海上での作業が少なく，工期が短縮できるという利 点がある1).この浮体橋の設計 ${ }^{2}$ に当たっては, 構造の弾 性影響を考慮した浮体橋の風と波作用下での挙動を把握 する必要がある，そのためには，風と波作用下での浮体 橋の挙動解析法の開発が必要となるが, 同時にその解析 法を検証するための実験データが必要である.

実験的に浮体橋の挙動を計測した例としては，造波水 槽に浮体橋剛体模型を浮か心，波と風荷重に相当する力 をアクチュエータで作用させた例尚4)，回転ピンと軸受 台車を中心とした波浪中旋回試験の例 ${ }^{5)}$, 弾性模型とし

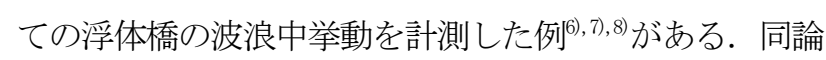
文 $^{(6), 7)}$ の規則波応答の実験では，固有周期付近において 応答のピークが生じやすく, 桁は弾性変形の影響が大き くなると検証されている.
著者ら ${ }^{9), 10}$ は大規模風洞の風路内に設置された造波水 槽内に実機対応の弾性構造の浮体橋を風と波の方向に対 して橋軸直角方向に浮かべた状態で動摇実験を行った. ここで, 浮体橋を構成する桁はゴム防舷材対応の係留装 置11により, ポンツーンはカテナリー特性の線形バネに より係留し, 外力として波と, 高さ方向に速度分布を持 つ境界層乱流としての自然風対応の風を同時に作用させ

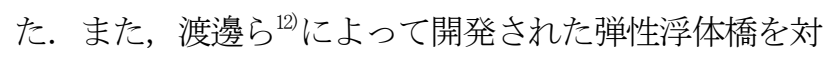
象とした波浪応答シミュレーションプログラムを用いて， 外力が規則波単独の場合の周波数応答解析結果と比較し $た^{13)}$. 同論文9), 10)では，風や波を外力として受ける場合 に, 浮体橋模型は実機対応として設計されていたので, 比較的弾性応答が小さかった. よって, 桁の様々な振動 モード特性を確認すること，および橋軸に対して斜め方 向から風や波が入射する場合の応答特性を検証すること， が今後の課題とされた.

本研究では, 大規模風洞の風路内に設置された造波水 槽内に係留された浮体橋の弾性応答現象を観測しや寸く するために, 浮体橋模型の桁部分の骨組となる岡性棒の 

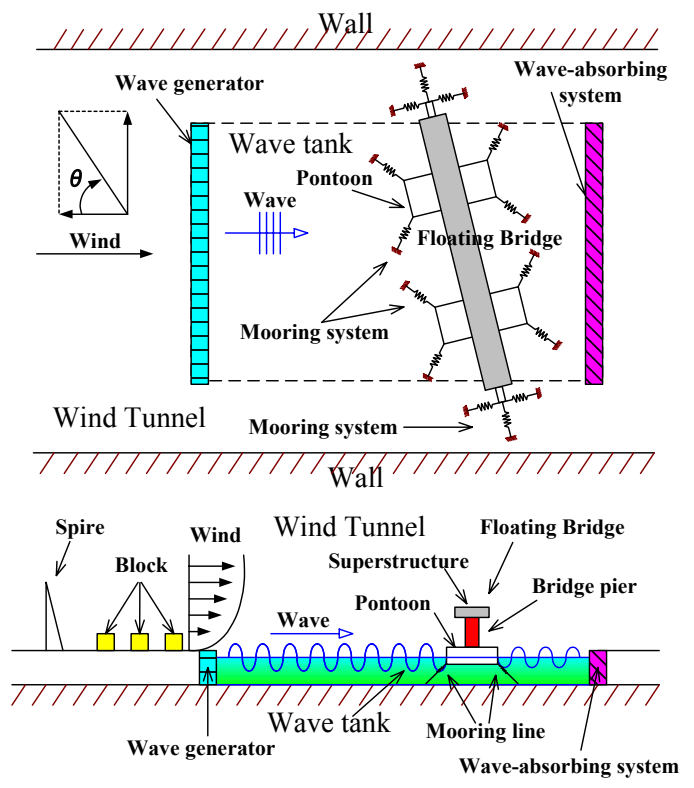

図-1 実験概要図

岡性を想定実機よりも小さくなるように設計し現象の知 見を得やすくした.

そして，2種類の偏角（橋直方向，橋斜方向）に対し て係留された分離ポンツーン型浮体橋の風・波作用下で の動摇実験を行った.

得られた実験結果より，風・波を同時に受ける浮体橋 の動的応答特性を検証する。また，波浪中弾性挙動に関

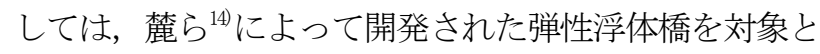
した波浪応答シミュレーションプログラムを用いて，計 算結果と比較した.

\section{2. 実験方法}

\section{(1) 実験装置}

実験は，図-1に示すように，日立造船（株）所有のゲ ッチンゲン型風洞で実施した。風路の測定部寸法は，長

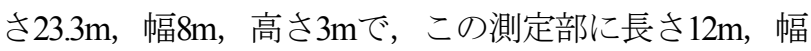
$5.4 \mathrm{~m}$ ，深さ $0.22 \mathrm{~m}$ の造波水槽を設置した。この水槽は， 設置や撤去を容易にし，かつ水槽自体の重量を低減する ために，鋼鉄製の骨組構造に底板としての発泡材と側板 としてのベニヤ板を取付け，水漏れ防止のため，水槽内 側にポリエステル繊維の織物を軟質な合成樹脂フィルム で挟んだビニール系の素材であるターポリンシートを張 り付けた構造である.

\section{(2) 供試模型}

浮体橋模型は，図-2に示すように，2個のポンツーン， 弾性体としての鋼鉄製の岡性棒に桁外形材を取り付けた 上部工，上部工とポンツーンを繋ぐ橋脚から成る.この
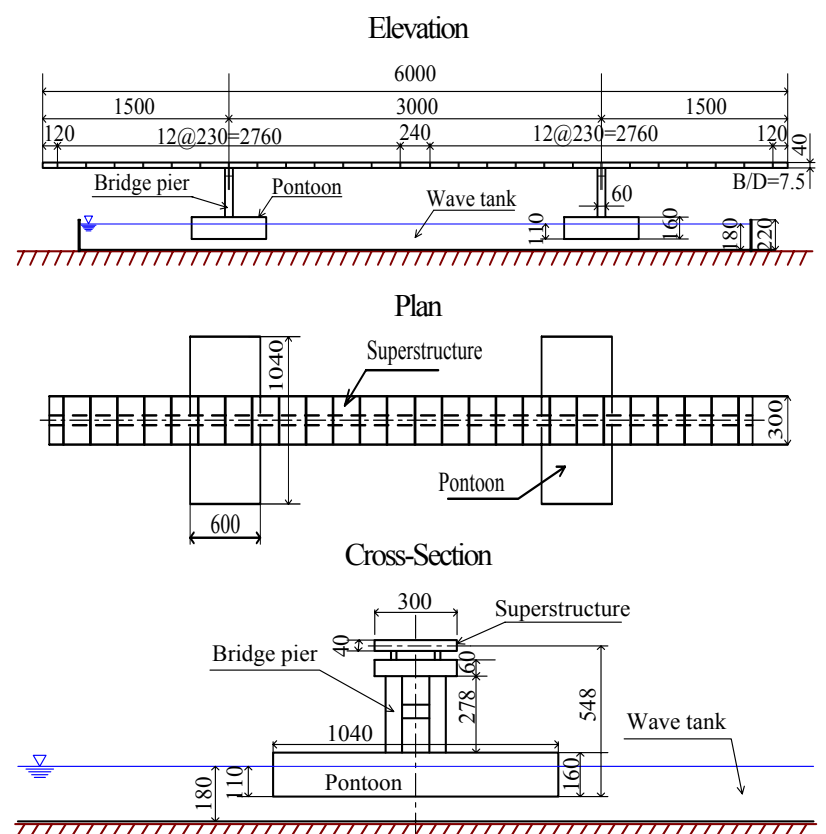

図-2 浮体橋模型（単位:mm）

表-1 設計条件

\begin{tabular}{|l|l|}
\hline Formality & consecutive box girder bridge holded seven spans \\
\hline The number of main girder & two main girder (about structural basic line) \\
\hline Length of effective span & $1050[\mathrm{~m}]$ \\
\hline Height of girder & $5000[\mathrm{~mm}]$ \\
\hline Floor slab & steel slab \\
\hline Pavement & asphalt pavement \\
\hline Spent steel & make meet Japanese Industrial Standards \\
\hline A kind of steel & Depend on specifications for highway bridges \\
\hline Weathering steel & Out of use \\
\hline
\end{tabular}

浮体橋模型は分離ポンツーン型で，2車線の自動車専用 道路用の 7 径間連続鋼床版箱桁橋として，その中央部を 対象にしたものである. 模型の縮尺率は $1 / 50 て ゙ ，$ 流体に 関する相似則にはフルード則を用いた。桁外形材は，ブ ロック長を228mmとし，桁全体を弾性模型として檜材を 用いて製作した，表-1に検討対象とした実橋の設計条件 を，表-2に浮体橋の実橋と模型の主要寸法を，表-3に桁 の断面諸量を示す．想定した実橋の上部工桁高は $5 \mathrm{~m}$

（桁幅と桁高の比： B/D=3.0）であるが，模型の上部工 高さは実橋で $2 \mathrm{~m} （ \mathrm{~B} / \mathrm{D}=7.5)$ として対応寸る值に変更し ている.これは $\mathrm{B} / \mathrm{D}=7.5$ の桁断面に関しては, 2次元断面 を対象とした静的空気力係数が，別途，風洞実験で詳細 に計測されており，本実験に対応する動摇シミュレーシ ヨン計算 ${ }^{14}$ を行う場合, 外力である風荷重を入力寸る際 に必要な抗力係数として利用できるからである.

図-3に示寸ように，剛性棒の断面はH型とし，橋軸方 向の弾性梁とした. 表-3に示した析断面岡性Iy，Iz，Ipは それぞれ想定実機の1/2，1/4，1/46として実験で弾性影響 が顕著に現れるようにしている，ポンツーンと橋脚はネ ジ止めによる剛結合で，それぞれは剛体模型である. 
表-2 主要寸法

\begin{tabular}{|l|r|r|}
\hline \multicolumn{1}{|c|}{ Dimensions } & \multicolumn{1}{c|}{ Real } & Model $(1 / 50)$ \\
\hline \hline Length of floating bridge & $300.0(\mathrm{~m})$ & $6.00(\mathrm{~m})$ \\
\hline Length between two bridge pier & $150.0(\mathrm{~m})$ & $3.00(\mathrm{~m})$ \\
\hline Breadth B & $15.0(\mathrm{~m})$ & $0.30(\mathrm{~m})$ \\
\hline Height of superstructure & $5.0(\mathrm{~m})$ & $0.04(\mathrm{~m})$ \\
\hline B/D & \multicolumn{1}{c|}{3.0} & 7.5 \\
\hline Height of bridge pier & $18.0(\mathrm{~m})$ & $0.36(\mathrm{~m})$ \\
\hline Length of pontoon & $52.0(\mathrm{~m})$ & $1.04(\mathrm{~m})$ \\
\hline Breadth of pontoon & $30.0(\mathrm{~m})$ & $0.60(\mathrm{~m})$ \\
\hline Height of pontoon & $8.0(\mathrm{~m})$ & $0.16(\mathrm{~m})$ \\
\hline Draft & $5.5(\mathrm{~m})$ & $0.11(\mathrm{~m})$ \\
\hline Displacement volume & $8579\left(\mathrm{~m}^{3}\right)$ & $68640(\mathrm{~cm})$ \\
\hline KG & $13.16(\mathrm{~m})$ & $26.32(\mathrm{~cm})$ \\
\hline GM & $30.57(\mathrm{~m})$ & $61.14(\mathrm{~cm})$ \\
\hline
\end{tabular}

表-3 桁の断面諸量

\begin{tabular}{|c|c|c|c|}
\hline \multirow{3}{*}{$\begin{array}{l}\text { Section } \\
\text { modulus }\end{array}$} & Iz (Vertical rigidity) & 4169.5 & \multirow{3}{*}[\mathrm{mm}^{4}]{} \\
\hline & Iy (Horizontal rigidity) & 30543.3 & \\
\hline & Ip (Torsional rigidity) & 278.7 & \\
\hline \multirow{2}{*}{\multicolumn{2}{|c|}{ Polar moment of inertia }} & 1.77 & {$[\mathrm{~kg} / \mathrm{m}]$} \\
\hline & & $1.49 \mathrm{E}-02$ & {$\left[\mathrm{~kg} \cdot \mathrm{m}^{2} / \mathrm{m}\right]$} \\
\hline
\end{tabular}

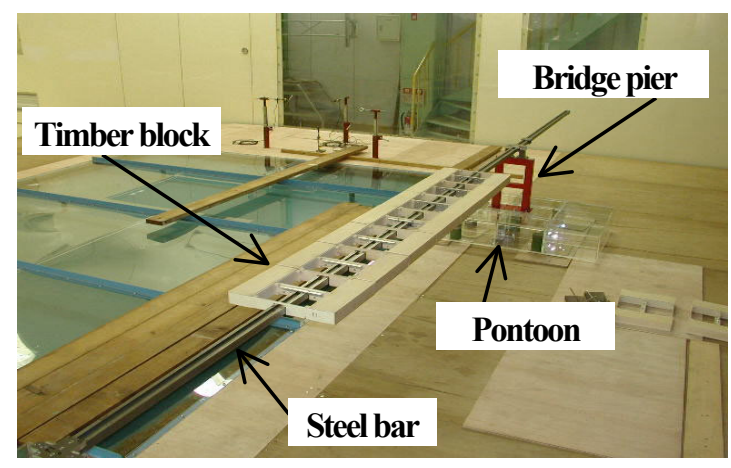

図-3 桁内部構造

橋脚と桁との取り合い部分である支承部分は，鉛直方 向と橋軸方向に各々板バネを介した弾性結合としてモデ ル化している．また，実験前準備としてポンツーンの慣 動半径と桁の極慣性モーメントを計測し, 自由振動試験 を行って浮体橋模型の固有振動数とモード形状を計測し た．これらの測定值は，模型設計の解析值と同等になる ように，上部工，橋脚，ポンツーン，それぞれに錘を配 置して調整している.

\section{(3) 供試模型の動的特性}

浮体橋弾性模型は, 桁の振動モードとポンツーンの運 動モードについて，それぞれが動的特性(モード形状, 振動数)を有する. また, ポンツーン自体は係留されて いるので, ポンツーンの動的特性は係留特性に依存する.
表-4 浮体橋模型の動的特性

\begin{tabular}{|l|c|c|}
\hline \multicolumn{1}{|c|}{ Direction } & \multicolumn{1}{c|}{$\begin{array}{c}\text { Superstructure } \\
\text { +Pontoon }\end{array}$} & Natural frequency \\
\hline \hline Direction of the bridge axis & Surging & $0.53[\mathrm{~Hz}]$ \\
\hline $\begin{array}{l}\text { Horizontal direction } \\
\text { transverse to the bridge axis }\end{array}$ & Swaying & $0.42[\mathrm{~Hz}]$ \\
\hline Vertical direction & Heaving & $0.75[\mathrm{~Hz}]$ \\
\hline $\begin{array}{l}\text { Direction around the bridge } \\
\text { axis }\end{array}$ & Rolling & $0.80[\mathrm{~Hz}]$ \\
\hline Direction around vertical axis & Yawing & $0.52[\mathrm{~Hz}]$ \\
\hline \hline \multicolumn{1}{|c|}{ Direction } & Superstructure & Natural frequency \\
\hline \hline $\begin{array}{l}\text { Horizontal direction } \\
\text { transverse to the bridge axis }\end{array}$ & First symmetry mode & $2.48[\mathrm{~Hz}]$ \\
\cline { 2 - 3 } & First anti-symmetry mode & $4.94[\mathrm{~Hz}]$ \\
\hline \multirow{3}{*}{ Vertical direction } & First symmetry mode & $1.35[\mathrm{~Hz}]$ \\
\cline { 2 - 3 } & First anti-symmetry mode & $2.07[\mathrm{~Hz}]$ \\
\cline { 2 - 3 } & Second symmetry mode & $3.76[\mathrm{~Hz}]$ \\
\hline Torsional direction & First symmetry mode & $4.31[\mathrm{~Hz}]$ \\
\hline
\end{tabular}

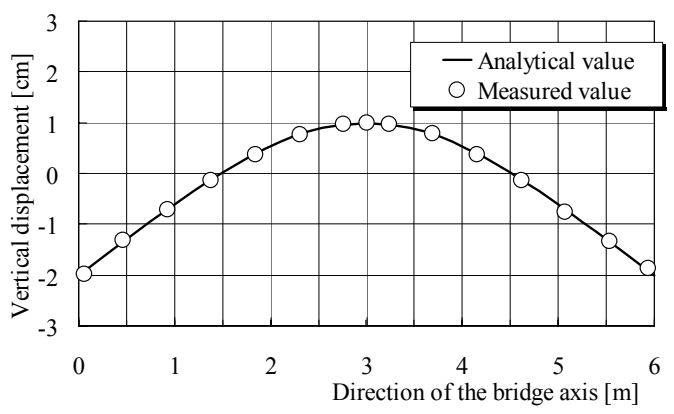

図-4 鉛直対称1次モード

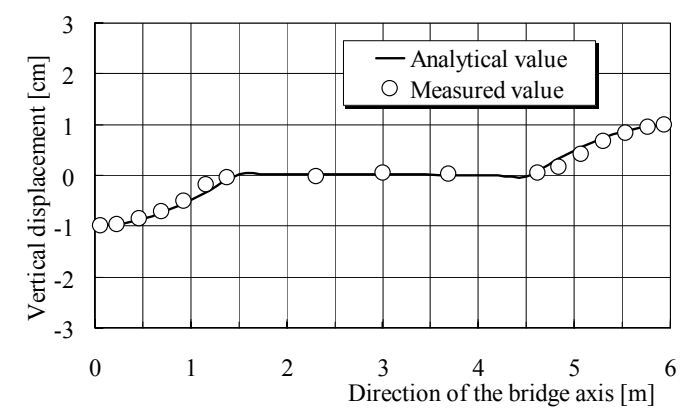

図-5鉛直逆対称モード

そこで，桁とポンツーンの各部位が係留された浮体橋 模型を水面に浮かべた状態で, 桁の主要振動モードは加 振機で桁部を強制加振させてFFTアナライザーを用いて 計測し，ポンツーンの運動モードはポンツーンの復原力 のある方向に強制力を与えて自由動摇させて減衰曲線か ら算出した. 固有振動数の計測結果を表-4に示す. また, 図-4と図-5に示すように, 計測結果と桁剛性棒の設計值 を用いた骨組モデルの解析值とを比較した結果，模型測 定值は解析値とほぼ一致した。

\section{(4) 計測位置}

計測に使用したセンサーの配置図を図-6に，表-5にセ ンサー設置位置と名称の対応表を示す．図-7に実際の配 置の様子を示寸. 本実験では, 風や波の外力下における 


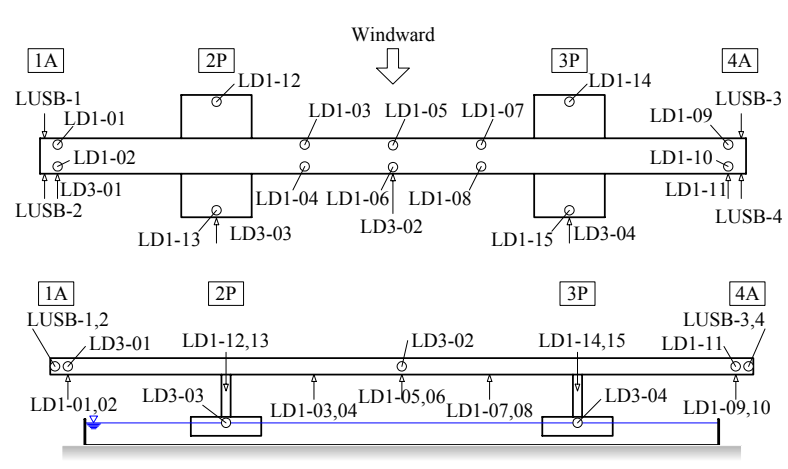

図-6 センサー位置

表-5 センサー位置対応表

\begin{tabular}{|c|c|c|c|}
\hline Measuring points & Direction & Measuring instruments & Number \\
\hline \multirow{3}{*}{$\begin{array}{l}\text { 1A point of Edge of } \\
\text { Superstructure }\end{array}$} & $\begin{array}{l}\text { Displacement of superstructure : } \\
\left\{\begin{array}{l}\cdot \text { Vertical (LD1-01, LD1-02) } \\
\cdot \text { Horizontal (LD3-01) }\end{array}\right. \\
\end{array}$ & $\begin{array}{l}\text { Laser displacement } \\
\text { meter }\end{array}$ & $\begin{array}{l}2 \\
1 \\
\end{array}$ \\
\hline & \begin{tabular}{|c|} 
Load acting on mooring spring : \\
$\cdot$ Horizontal (LUSB-1, LUSB-2) \\
\end{tabular} & Load cell & 2 \\
\hline & \begin{tabular}{|r|} 
Displacement of mooring spring : \\
$\cdot$ Horizontal (LD1-07, LD1-08) \\
\end{tabular} & \multirow{5}{*}{$\begin{array}{l}\text { Laser displacement } \\
\text { meter }\end{array}$} & 2 \\
\hline $\begin{array}{c}\mathrm{L} / 4 \text { point of Center } \\
\text { span }\end{array}$ & $\begin{array}{c}\text { Displacement of superstructure : } \\
\text { • Vertical (LD1-03, LD1-04) }\end{array}$ & & 2 \\
\hline $\begin{array}{l}\mathrm{L} / 2 \text { point of Center } \\
\text { span }\end{array}$ & \begin{tabular}{|l|} 
Displacement of superstructure \\
$\left\{\begin{array}{l}\cdot \text { Vertical (LD1-05, LD1-06) } \\
\cdot \text { Horizontal (LD3-02) }\end{array}\right.$ \\
\end{tabular} & & $\begin{array}{l}2 \\
1\end{array}$ \\
\hline $\begin{array}{c}3 \mathrm{~L} / 4 \text { point of Center } \\
\text { span }\end{array}$ & $\begin{array}{c}\text { Displacement of superstructure : } \\
\text { • Vertical (LD1-07, LD1-08) }\end{array}$ & & 2 \\
\hline \multirow{3}{*}{$\begin{array}{l}\text { 4A point of Edge of } \\
\text { Superstructure }\end{array}$} & $\begin{array}{l}\text { Displacement of superstructure : } \\
\left\{\begin{array}{l}\cdot \text { Vertical (LD1-09, LD1-10) } \\
\cdot \text { Horizontal (LD3-03) }\end{array}\right.\end{array}$ & & $\begin{array}{l}2 \\
1\end{array}$ \\
\hline & \begin{tabular}{|c|} 
Load acting on mooring spring : \\
$\cdot$ Horizontal (LUSB-3, LUSB-4) \\
\end{tabular} & Load cell & 2 \\
\hline & \begin{tabular}{|r|} 
Displacement of mooring spring : \\
$\cdot$ Horizontal (LD1-11, LD1-12) \\
\end{tabular} & $\begin{array}{c}\begin{array}{c}\text { Laser displacement } \\
\text { meter }\end{array} \\
\end{array}$ & 2 \\
\hline $\begin{array}{c}\text { Neighborhood of Wave } \\
\text { generator }\end{array}$ & Incident wave & \multirow{4}{*}{ Wave height meter } & 2 \\
\hline 2P Pontoon & \multirow{2}{*}{ Windward } & & 1 \\
\hline 3P Pontoon & & & 1 \\
\hline $\begin{array}{c}\text { Neighborhood of } \mathrm{L} / 2 \\
\text { point of Center span }\end{array}$ & Leeward & & 2 \\
\hline
\end{tabular}

浮体橋模型各部位の動摇および振動変位，桁端部に働く 係留反力，波高をそれぞれ計測した.

\section{3. 実験条件}

\section{(1) 実験ケ一ス}

外力として，(1)風が単独で作用寸る場合，(2)波が単 独で作用する場合，(3)風と波が同時に作用する場合の3 タイプを対象に実験を実施した。それぞれ外力 3 タイプ について，図-1に示寸ように，浮体橋を風や波が入射寸 る方向と橋軸のな寸角 $\theta$ が75 deg (橋斜方向), $90 \mathrm{deg}$ (橋直 方向)の2通りの位置にそれぞれ設置した.

表-6に示寸ように，(1)と（3）の場合において風は，高 さ方向に速度分布をもつ境界層乱流である．（1）の場合 における風速(実橋換算值)は，3m/s〜 $50 \mathrm{~m} / \mathrm{s}$ の間で $6 \mathrm{~m} / \mathrm{s} ヒ ゚$ ッチで変化させた．また，(3)の場合において風は桁位 置の高さの風速が暴風時対応の設計風速となる $43 \mathrm{~m} / \mathrm{s}$ (風

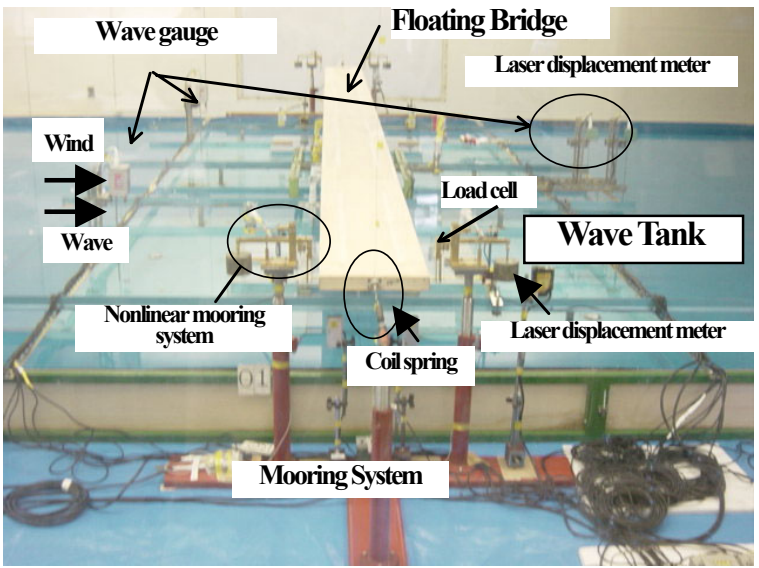

図-7 計測位置

表-6＼cjkstart実験ケース

\begin{tabular}{|c|c|c|c|c|}
\hline \multirow{2}{*}{$\begin{array}{l}\text { Type of External } \\
\text { force }\end{array}$} & \multirow{2}{*}{\begin{tabular}{|c|} 
Wave frequency \\
(Value to model)
\end{tabular}} & Wave period & Wind velocity & \multirow{2}{*}{$\theta$} \\
\hline & & \multicolumn{2}{|c|}{$\begin{array}{l}\cdot \text { Upper : Value to model } \\
\cdot{ }_{\text {Lower }} \text { : Conversion value to actual bridge }\end{array}$} & \\
\hline \multirow{2}{*}{ In winds } & \multirow{2}{*}{-} & \multirow{2}{*}{-} & $101 \mathrm{~m} / \mathrm{s} \sim 10 \mathrm{~m} / \mathrm{s}$ & \multirow{2}{*}{$90 \mathrm{deg}, 75 \mathrm{deg}$} \\
\hline & & & $3 \mathrm{~m} / \mathrm{s} \sim 50 \mathrm{~m} / \mathrm{s}$ & \\
\hline \multirow{2}{*}{ In waves } & \multirow{2}{*}{$0.5 \mathrm{~Hz} \sim 2 \mathrm{~Hz}$} & $0.5 \mathrm{~s} \sim 2 \mathrm{~s}$ & \multirow{2}{*}{-} & \multirow{2}{*}{$90 \mathrm{deg}, 75 \mathrm{deg}$} \\
\hline & & $3.5 \mathrm{~s} \sim 14 \mathrm{~s}$ & & \\
\hline \multirow{2}{*}{$\begin{array}{l}\text { In winds and } \\
\text { waves }\end{array}$} & \multirow{2}{*}{$0.5 \mathrm{~Hz} \sim 2 \mathrm{~Hz}$} & $0.5 \mathrm{~s} \sim 2 \mathrm{~s}$ & $8.5 \mathrm{~m} / \mathrm{s}$ & \multirow{2}{*}{$90 \mathrm{deg}, 75 \mathrm{deg}$} \\
\hline & & $3.5 \mathrm{~s} \sim 14 \mathrm{~s}$ & $43 \mathrm{~m} / \mathrm{s}$ & \\
\hline
\end{tabular}

表-7 入射波高（両振幅值）

\begin{tabular}{|c|c|c|c|}
\hline \multicolumn{2}{|c|}{ Wave period } & Wave frequency & Wave height \\
\hline Real[s] [ & Model[s] & {$[\mathrm{Hz}]$} & {$[\mathrm{mm}]$} \\
\hline \hline 14.14 & 2.00 & 0.50 & 8.16 \\
\hline 11.79 & 1.67 & 0.60 & 11.26 \\
\hline 10.1 & 1.43 & 0.70 & 10.70 \\
\hline 8.84 & 1.25 & 0.80 & 15.10 \\
\hline 7.86 & 1.11 & 0.90 & 17.62 \\
\hline 7.07 & 1.00 & 1.00 & 24.06 \\
\hline 5.89 & 0.83 & 1.20 & 12.92 \\
\hline 5.05 & 0.71 & 1.40 & 17.32 \\
\hline 4.42 & 0.63 & 1.60 & 17.16 \\
\hline 3.93 & 0.56 & 1.80 & 14.24 \\
\hline 3.54 & 0.50 & 2.00 & 15.58 \\
\hline
\end{tabular}

洞風速 $8.5 \mathrm{~m} / \mathrm{s}$ ) に設定して入射波の波周波数を変化させた. (2) と（3)の場合における波周波数 (模型値) は， $0.5 \mathrm{~Hz} \sim$ $2.0 \mathrm{~Hz}$ の間で $0.1 \mathrm{~Hz}$ ごとに，波周期を実橋換算值で表すと， $4 \mathrm{~s} \sim 15 \mathrm{~s}$ の範囲内として設定した．入射波高は浮体橋模 型のない状態で検定し，測定結果を表-7に示す．風波の 波高の最大期待值は表-8に示す。 hl は造波板付近の波高 を，h2はポンツーン付近の波高を示している．実験では 風の作用で水槽内に発生する風波の最大波高は非常に小 さい，また，計測データ処理の際には，水槽壁による反 射波の影響分を除去するため，吹奏時間としては短い範 囲を対象とし，h1位置とh2位置での風波の波高值が次第 に大きくなる様子から風波としての完全発達状態に達し ていないと予測される。 また, 水槽の水深は $18 \mathrm{~cm}$ で, 実橋換算值は 9mである. 図-8に実際の実験状況を示す。 
表-8 風波の波高（両振幅值）

\begin{tabular}{|c|c|c|c|}
\hline \multicolumn{2}{|c|}{ Wind velocity [m/s] } & \multicolumn{2}{c|}{ Wave height [mm] } \\
\hline Real & Model & Generator(h1) & Pontoon(h2) \\
\hline \hline 2.7 & 0.5 & 0.40 & 0.42 \\
\hline 7.9 & 1.6 & 0.40 & 0.41 \\
\hline 13.0 & 2.5 & 0.49 & 0.57 \\
\hline 18.0 & 3.5 & 0.60 & 0.77 \\
\hline 23.0 & 4.5 & 0.88 & 0.99 \\
\hline 28.0 & 5.5 & 1.25 & 2.08 \\
\hline 33.3 & 6.5 & 1.47 & 3.19 \\
\hline 38.4 & 7.5 & 1.85 & 3.81 \\
\hline 43.5 & 8.5 & 1.95 & 4.80 \\
\hline
\end{tabular}

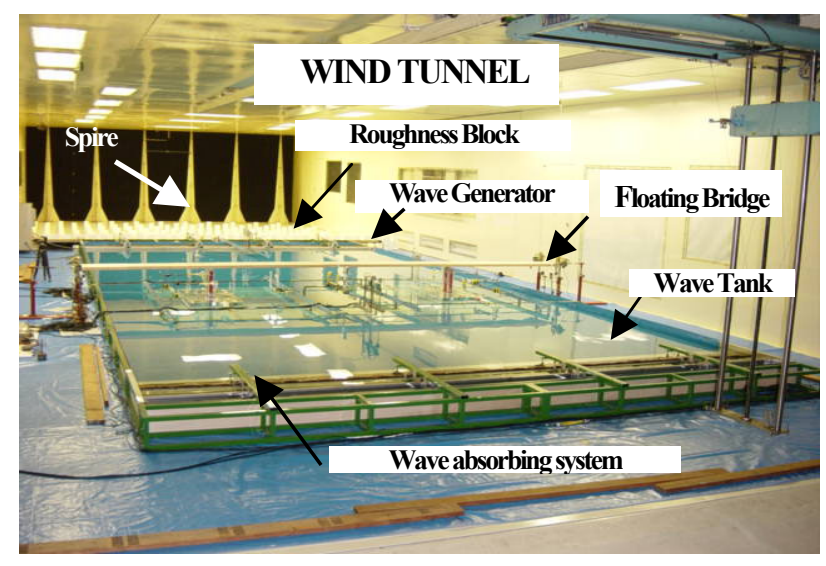

図-8 実験の様子
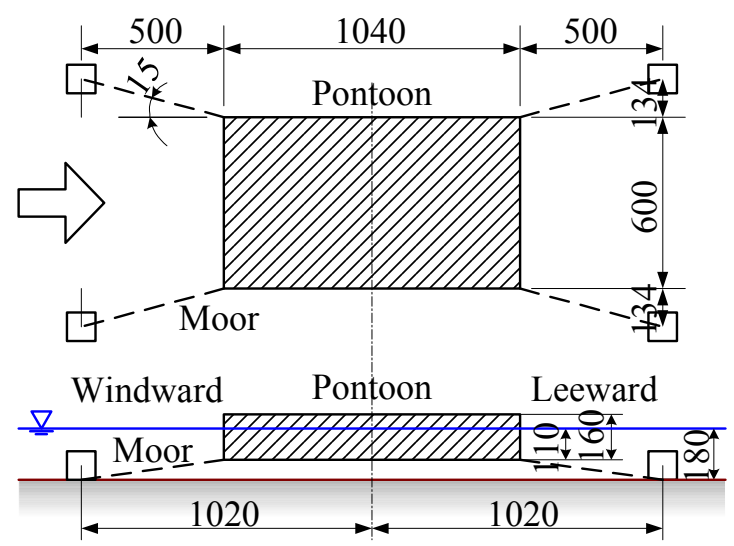

図-9 ポンツーンの係留

\section{(2) 係留方法}

ポンツーンの係留配置図を図-9 に示す. 図-10 に示す ように，ポンツーンおよび桁端の鉛直方向と橋軸方向の 各バネ 1 本分のバネ定数について，それぞれ $2 \mathrm{P}(1) \sim(4)$ および $3 \mathrm{P}(1) \sim(4)$ は $2.8 \mathrm{~N} / \mathrm{cm} ， 2 \mathrm{P}(5)$ おび $3 \mathrm{P}(5)$ は $0.39 \mathrm{~N} / \mathrm{cm}$, 2P(6)〜(7)および 3P(6)〜(7)は 3.9N/cm と設定した. また， 20\%の歪を想定したゴム防舷材を，図-11 に示すような 板バネを用いて模擬した非線形係留装置として，桁端部 の上下流側に 2 基ずつ，計 4 基設置した.

ここで，ポンツーンと桁端部のバネ定数は，実橋と想

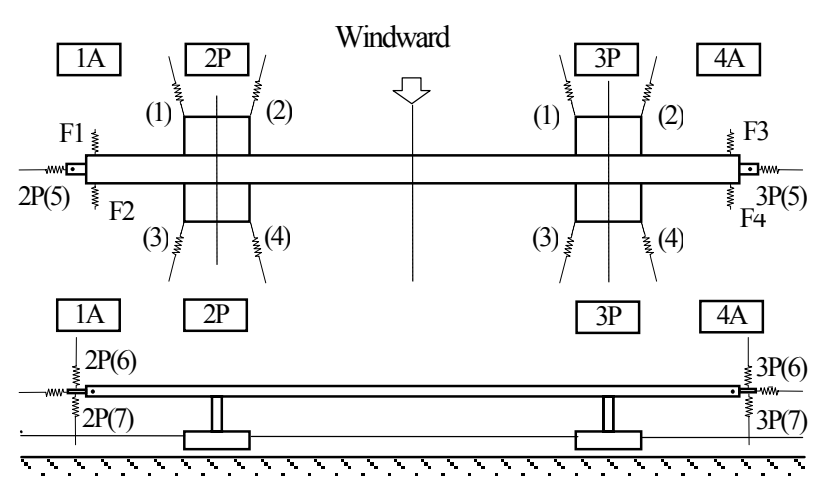

図-10 係留バネの配置と名称

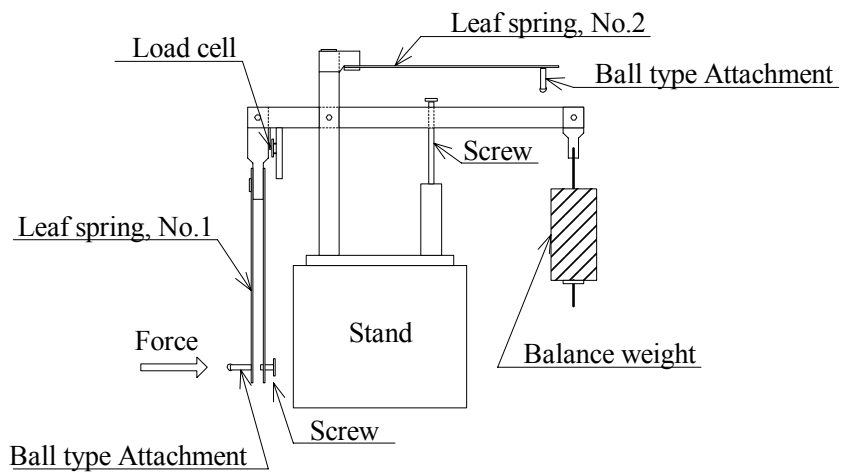

図-11 係留装置

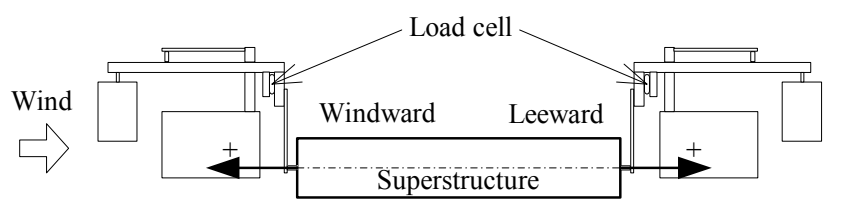

Displacement and Mooring force Compression (+)

Displacement and Mooring force Compression (+)

\section{図-12 係留装置設置図}

定した浮体橋の骨組構造解析を実施して, ポンツーンと 桁端部の変位が同程度となる值である。このとき, 解析 に関してポンツーンは浮力により支持されている（浮力 バネ）と仮定し，桁の両端はバネ支持として算出してい る. 図-12に非線形係留装置の設置状況を示す.この位 置は，図-10のF1〜F4である. 実際のゴム防舷材の反力 は，図-13の破線で示すように，防舷材歪に対して非線 形な反力特性を有している，そこで，本係留装置を板バ ネNo.1，板バネNo.2およびバランスウェイトから構成し， これらの部品による梃子の原理を利用することで，非線 形反力特性を変位一荷重の折れ線として近似している. 図-13の実線はそれぞれ配置した4つの非線形係留装置の 検定試験結果の実測值である. 


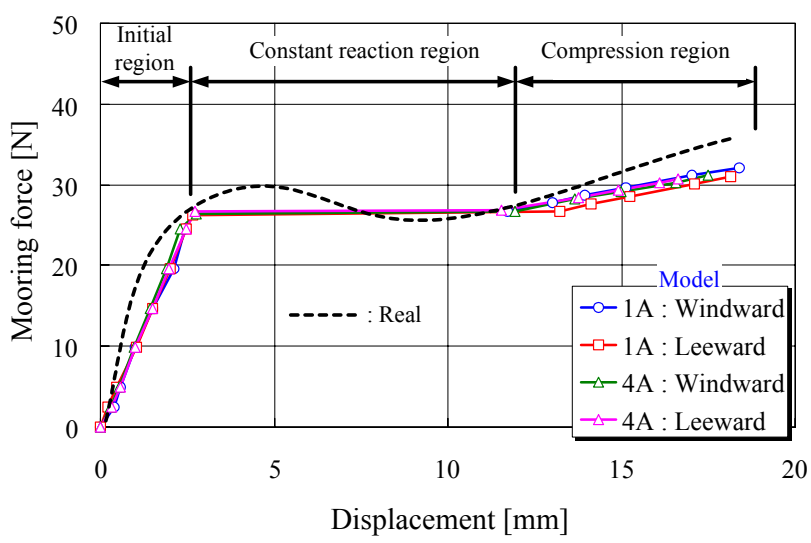

図-13 係留特性
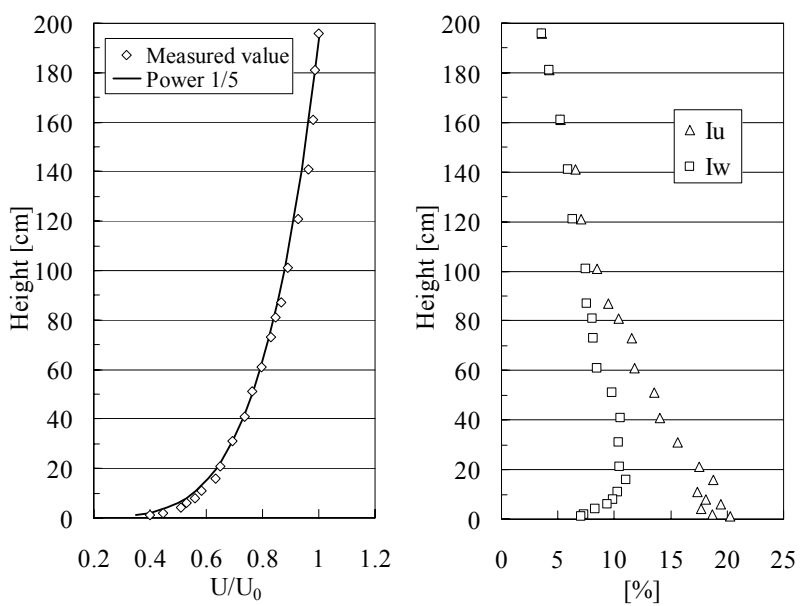

図-14 風速分布および乱れ強さ（平均風速 $5 \mathrm{~m} / \mathrm{s}$ )

\section{(3) 境界層乱流の特性}

風洞の風路床の上流側には，粗度ブロック，スパイヤ 一等を設置して，風に関して境界層乱流の実験ができる ようにしている. 浮体橋模型の設置場所近傍において所 定の境界層乱流になっているかどうかを調べた。

浮体橋模型設置位置の $1.6 \mathrm{~m}$ 上流で計測した気流の境界 層乱流特性を図-14に示す。この結果は，X型熱線流速 計を使用してサンプリング周波数 $100 \mathrm{~Hz}$ で計測した 20 秒 間の平均值である。実験で目標とした境界層乱流は，風 洞設備の性能より，鉛直方向の風速分布がべき指数 $1 / 5$ となる境界層乱流とした.

図より，水面上高さに対して平均風速べき分布は概小 再現できていることがわかる，また，水面から $44 \mathrm{~cm}$ 上 方の桁位置で，主流水平方向の風速の乱れ強さIuは $14 \%$ 程度，鉛直方向の風速の乱れ強さIwは10.5\%程度および 乱れスケールは60cm程度である。

\section{(4) 箱桁断面の空気力係数}

浮体橋模型上部工の箱形断面の枌幅と桁高比 $\mathrm{B} / \mathrm{D}=7.5$ の場合に関する静的空気力係数を図-15に示す.

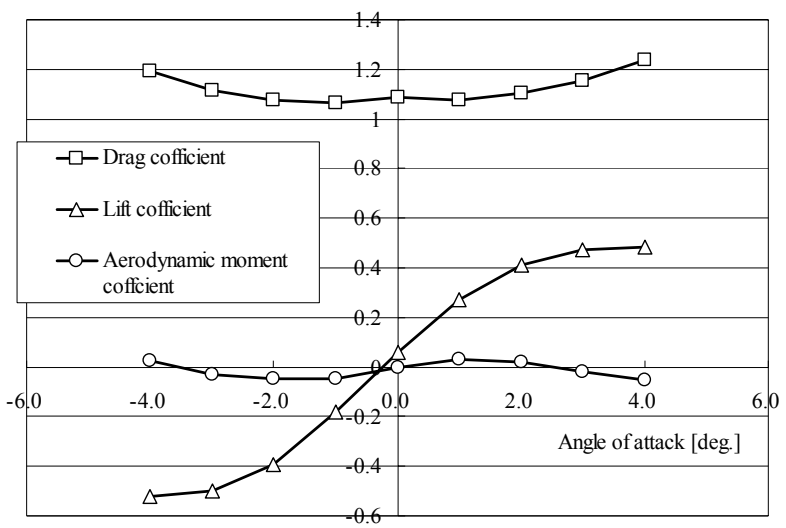

図-15 空気力係数

これは，別途行った2次元箱形断面に関する風洞実験 から得られたもので，一様流中に固定された箱型断面に 作用する空気力に関する抗力係数, 揚力係数, 空力モ一 メント係数である.

\section{4. 動摇実験および波浪応答解析の結果}

\section{(1) 実験データ解析法}

実験データ解析 ${ }^{15)}$ に関しては実験結果に対して次のよ うな前処理を行った。

先ず，低周波数成分の推定に歪が生じ，確率密度推定 に支障をきたす恐れのあるトレンドは最小自乗法を用い て除去した. このとき, 次数は4次の項まで考慮した.

次に，波が単独で作用する場合および風と波が同時に 作用する場合に関しては，造波板の加振によって発生す る規則波の群速度および造波板と浮体橋模型との距離か ら，入射波の第一波到達時間を求め，サンプリング時間 60秒間のデータから，入射波に対する浮体橋の動摇によ る反射波や水槽壁からの反射影響を実験データから取り 除いた。

また，外力3タイプのそれぞれに関しては，先ず，外 力として風が単独で作用する場合, 風は変動風により浮 体橋は不規則に動摇するため, 統計解析を行って応答の 両振幅の有義值および最大值を算出した．次に，規則波 が単独で作用する場合，ノイズ成分を除去するため, デ 一タ前処理で行った時系列データをフーリエ変換し，ノ イズ周波数成分を取り除いた後のデータを用いた.さら に，外力として変動風と規則波が同時に作用する場合， 規則波は変動風下において，造波板の加振周波数が卓越 する不規則波となるため, 浮体橋の応答時系列データは 統計解析を行った．また，規則波による周波数応答を算 出するためフーリエ解析も実施した. 


\section{(2)外力として風が単独で作用する場合}

図-16に，風向偏角 $\theta=90 \mathrm{deg}$.における風洞風速に対寸 る中央径間 $\mathrm{L} / 2$ 点の静的変形状況を示寸. 図より，ねじ れ変位については正迎角側にあり，桁側壁による頭上げ の空力モーメントの影響が現れている.

図-17に，風向偏角 $\theta=75 \mathrm{deg} .90 \mathrm{deg}$.における風洞風速に 対する桁端部1A下流側の静的係留力を示す. 図より, 斜風を受ける場合，作用寸る風荷重の水平成分は橋直方 向の風を受ける場合より小さいことを示している.

図-18に，風向偏角 $\theta=90 \mathrm{deg}$.における風洞風速に対寸 る桁端部1Aの係留力の両振幅最大值を示寸. 係留力の 值は上流側より下流側の方が大きい.これは，桁端部が 水平方向（橋軸直角方向）の風下側に変位していること を示している.また，上流側と下流側の係留力はそれぞ れの風速に対してほぼ10Nより小さく，図-13で示すよう に, 係留装置の線形領域の範囲内で桁端部が変位してい ることを表している.

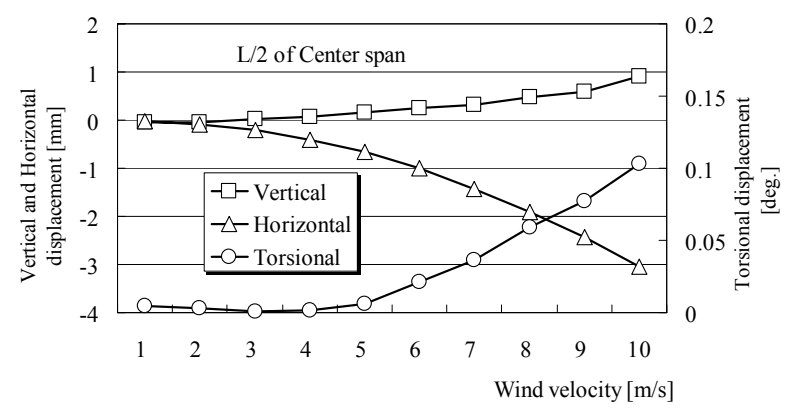

図-16 静的変形状況（風向偏角 $\theta=90 \mathrm{deg}$.)

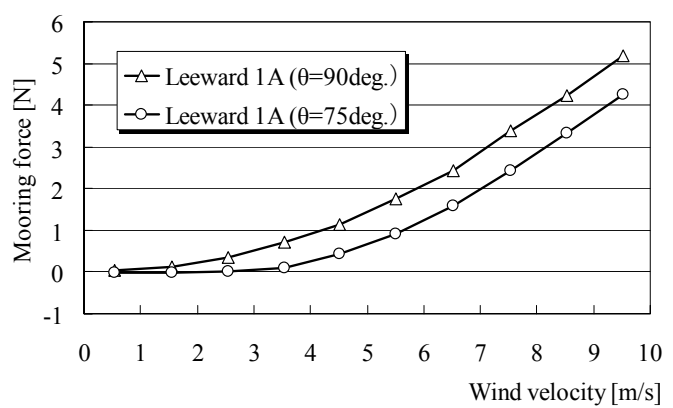

図-17 静的係留力

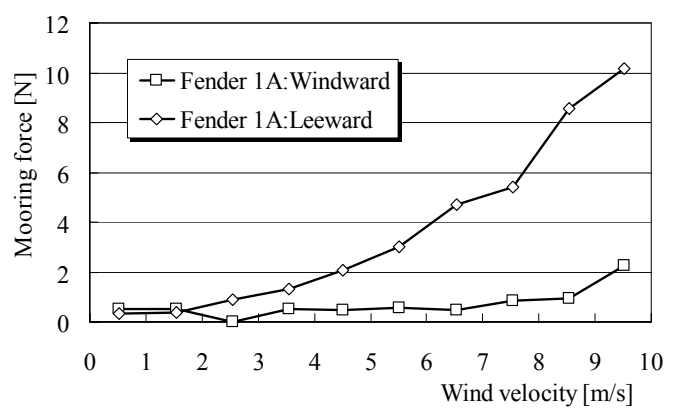

図-18 係留力の両振幅最大值（風向偏角 $\theta=90 \mathrm{deg}$.)
図-19に，風向偏角 $\theta=90 \mathrm{deg}$.における各々の風洞風速 に対する林端部1A, 中央径間 $\mathrm{L} / 2$ 点およびポンツーン $2 \mathrm{P}$ の鉛直方向，水平方向，水じれ方向の応答変位の両振幅 最大值を示寸. 図より, ガス卜応答特性を有しており, 鉛直方向について, 桁端部1Aの振動変位が中央径間 $\mathrm{L} 2$ 点の振動変位よりも大きいことを示している.これは 図-4に示寸鉛直対称1次モードが卓越しているためであ る.また，ポンツーンの動摇よりも桁の振動の方が大き い傾向がある，これは，表-8に示すように風の作用によ って発生した波高が小さい風波による2Pと3Pのポンツー ンの挙動よりも風のみによる杵の振動の方が，桁の弾性 応答も影響して, より大きくなったと推測される.

水平方向の変位に関しては, 暴風時を示寸風洞風速 $8.5 \mathrm{~m} / \mathrm{s}$ に対して, 中央径間 $\mathrm{L} / 2$ 点の水平変位は $2.2 \mathrm{~mm}$ （桁 幅の $0.74 \%$ ) 程度, ポンツーン2Pの水平変位（Sway）は $1.6 \mathrm{~mm}$ （ポンツーン幅の $0.16 \%$ ）程度であり, 鉛直方向 の変位に関しては, 風洞風速 $8.5 \mathrm{~m} / \mathrm{s}$ に対して, 中央径間 L/2点の鉛直変位は $8.9 \mathrm{~mm}$ （桁高さの $22.3 \% ）$ 程度, ポン ツーン2Pの鉛直変位 (Heave) は2.2mm（ポンツーン高さ の1.4\%) 程度である. また, 図より低風速域に発生しや すい渦励振および高風速域に発生しやすいフラッターな
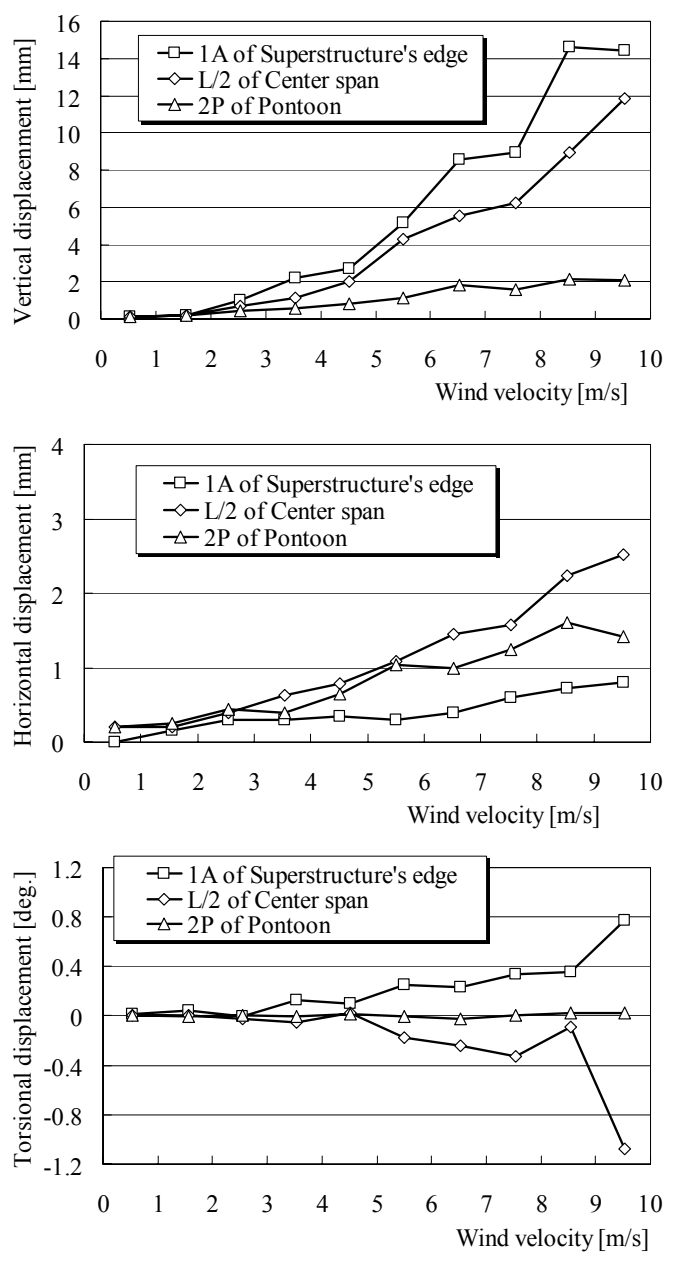

図-19 応答変位の両振幅最大值（風向偏角 $\theta=90 \mathrm{deg}$.) 


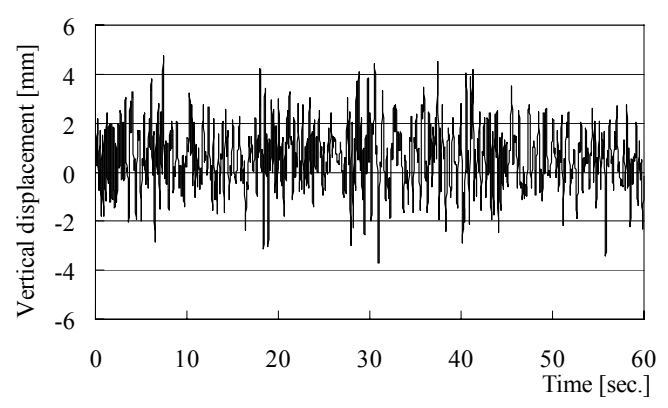

図-20 風洞風速 $8.5 \mathrm{~m} / \mathrm{s}$ における中央径間 $\mathrm{L} / 2$ 点の応答時系列 (風向偏角 $\theta=90 \mathrm{deg}$.)

どは想定風速内では確認されなかった，つまり，風を受 ける実験下でポンツーンの挙動などの影響で桁が不安定 な挙動を示すことはなかった.

これは，析断面は別途に行われた二次元風洞試験で渦 励振（乱流中で消滅）およびフラッター現象は観測され ていないことから，波荷重が加わった浮体橋としての複 合荷重状態でも対風応答の不安定化は起こらなかったと 推測される.

図-20は風洞風速 $8.5 \mathrm{~m} / \mathrm{s}$ の場合の中央径間 $\mathrm{L} / 2$ 点での応 答時系列を示し，この応答時系列のフーリエ振幅を図21に示寸. 図中の矢印で示寸ように表-4の鉛直方向の振 動モードがピークとして現れている.

実験水槽内に発生する風波の波高の両振幅最大值を 図-22に示寸，暴風時を示寸風洞風速 $8.5 \mathrm{~m} / \mathrm{s}$ の場合, 統計 解析した結果，造波板付近（沖側），ポンツーン $2 \mathrm{P}$ 上流 前方およびポンツーン2P上流後方（岸側）の有義波高と 有義波周期は，それぞれ $1.95 \mathrm{~mm}$ と $0.2 \mathrm{~s}$ 程度， $4.8 \mathrm{~mm}$ と 0.19s程度および9.1mmと0.24s程度であり，ポンツーンの 動摇に与える影響は小さいということが分かる.

以上より, 風単独の外力時には, 暴風時を想定した風 洞風速でも，本実験で発生する風波の影響によるポンツ ーンの応答は小さく, 桁の振動に関しては風の影響が主 で起こると推察される.

\section{(3)外力として波が単独で作用する場合}

それぞれの周波数の入射波に対して，著者の一人であ る麓ら ${ }^{14}$ の規則波応答解析法を用いた波浪応答シミュレ ーションを実施し，実験結果と比較した．図-23に波向 偏角 $\theta=75 \mathrm{deg}$.の場合および図-24に $\theta=90 \mathrm{deg}$.の場合のそ れぞれについて，応答を波高で除した周波数応答関数と して示寸.

いずれの結果も実験值と解析值は概小合致し，良好な 結果を示している.ここで, 波向偏角=75deg.の場合, ポ ンツーン2Pの鉛直変位のピークについて，入射波の波周 波数 $0.8 \mathrm{~Hz}$ 付近は鉛直方向のHeaveの固有振動数とほぼ対 応しており，応答が卓越している，そこで，この入射波

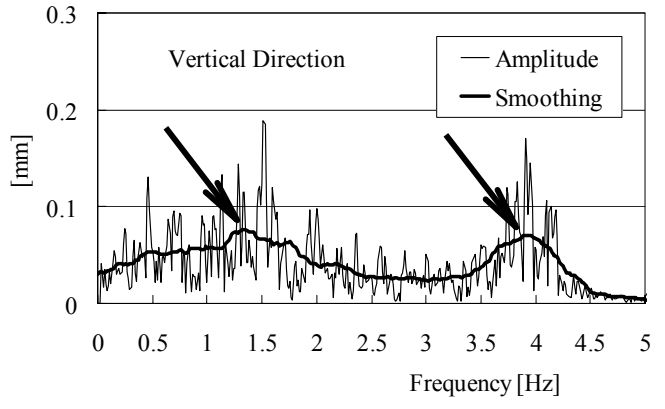

図-21 フーリエ振幅（風向偏角 $\theta=90 \mathrm{deg}$.)

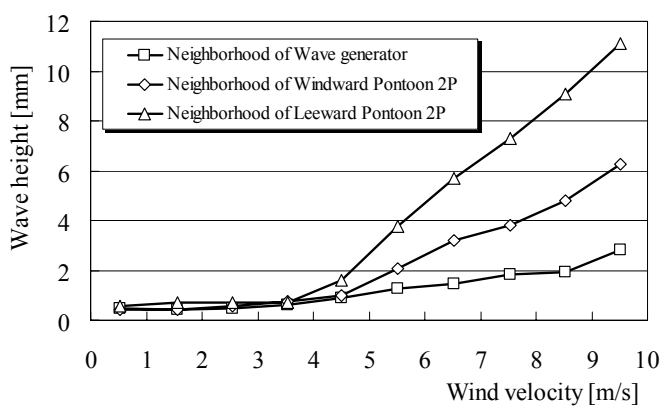

図-22 波高の両振幅最大值（風向偏角 $\theta=90 \mathrm{deg}$.)

の波周波数 $0.8 \mathrm{~Hz}$ に対するポンツーンと桁端部について それぞれ鉛直，水平，回転方向の各成分の応答時系列を 図-25 と図-26 に示寸. 図-25より，水平応答は鉛直応答 より大きくなっている.これは外力としての波周波数 $0.8 \mathrm{~Hz}$ は Roll の固有振動数と一致し, ポンツーンの横運 動の連成影響により，水平方向の運動も大きくなったと 考えられる.

図-27 は桁各部 1A，L/2，4A の時刻毎の振動変位から 各点の間の変位值を補間して求めた橋軸方向の桁の振動 分布を示す. ここで, $\mathrm{X} / \mathrm{L}=-0.25$ の位置はポンツーン $2 \mathrm{P}$ の設置位置を，X/L=0.25 の位置はポンツーン 3P の設置 位置を表している.

鉛直応答の振幅について，図-25と図-26より，波周波 数が浮体橋のHeaveの固有振動数とほぼ同值である $0.8 \mathrm{~Hz}$ 付近のとき, ポンツーンに関しては3P振幅值は2Pの振 幅值よりも若干大きく, 桁端部に関しては3P側の $4 \mathrm{~A} の$ 振幅值が2P側の1Aよりも1.6倍程大きい. また，1Aの振 幅値は2Pよりも1.3倍程大きく，4Aの振幅値は3Pよりも2 倍程大きい. これは図-27で示すような振動分布が林に 現れていると予測される. 図より桁端部の振動応答の大 きさを比較すると $1 \mathrm{~A}<4 \mathrm{~A}$ であり，2Pと3Pの橋軸位置X/L と同じ位置にある桁の振動応答の両振幅は $\overline{D 1 D 2}<$ $\overline{D 3 D 4}$ であることから，わずかながらポンツーンの応答 も2P<3Pとなっていることが推側できる.

水平応答の振幅について, 図-25と図-26より, ポンツ ーンに関しては3Pの振幅值は2Pの0.8倍程で, 桁端部に 関しては4Aの振幅值が1Aよりも1.3倍程大きい.また, 

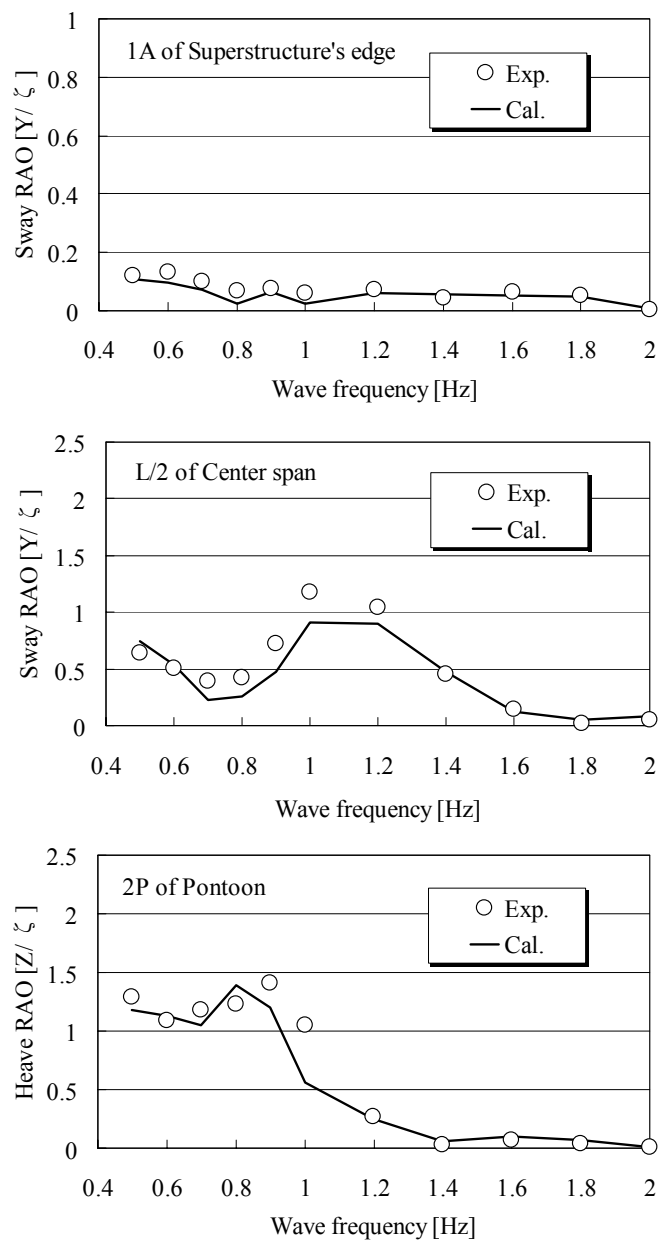

図-23 波向偏角 $\theta=75 \mathrm{deg}$.における運動の周波数応答関数

1Aの振幅值は2Pの0.12倍程で，4Aの振幅值は3Pよりも0.2 倍程である．桁端部の振幅がポンツーンより小さいのは, 水平方向の係留が影響していると推察される.これは 図-27で示寸ような振動分布が析に現れていると予測さ れる. 図より桁端部の振動応答の大きさを比較すると $1 \mathrm{~A}<4 \mathrm{~A}$ であり，2Pと3Pの橋軸位置X/と同じ位置にある 桁の振動応答の両振幅は $\overline{D 1 D 2}>\overline{D 3 D 4}$ であることから， ポンツーンの応答も $2 \mathrm{P}>3 \mathrm{P}$ となっていることが推側でき る.

回転（ねじれ）応答の振幅について，図-25と図-26よ り，波周波数が浮体橋のRollの固有振動数と同值である $0.8 \mathrm{~Hz}$ のとき, ポンツーンに関しては3 $\mathrm{P}$ の振幅值は $2 \mathrm{P} の$ 1.1倍程で，桁端部に関しては4Aの振幅值が1Aよりも 1.2 倍程大きい. また，1Aの振幅值は2Pよりも1.2倍程大き く, 4Aの振幅值は3Pよりも1.2倍程大きい. これは図-27 で示すような振動分布が桁に現れていると予測される.

図より桁端部の振動応答の大きさを比較すると $1 \mathrm{~A}<4 \mathrm{~A}$ であり，2Pと3Pの橋軸位置X/Lと同じ位置にある桁の振 動応答の両振幅はわずかではあるが, $\overline{D 1 D 2}<\overline{D 3 D 4}$ で あることから，ポンツーンの応答も $2 \mathrm{P}<3 \mathrm{P}$ となっている
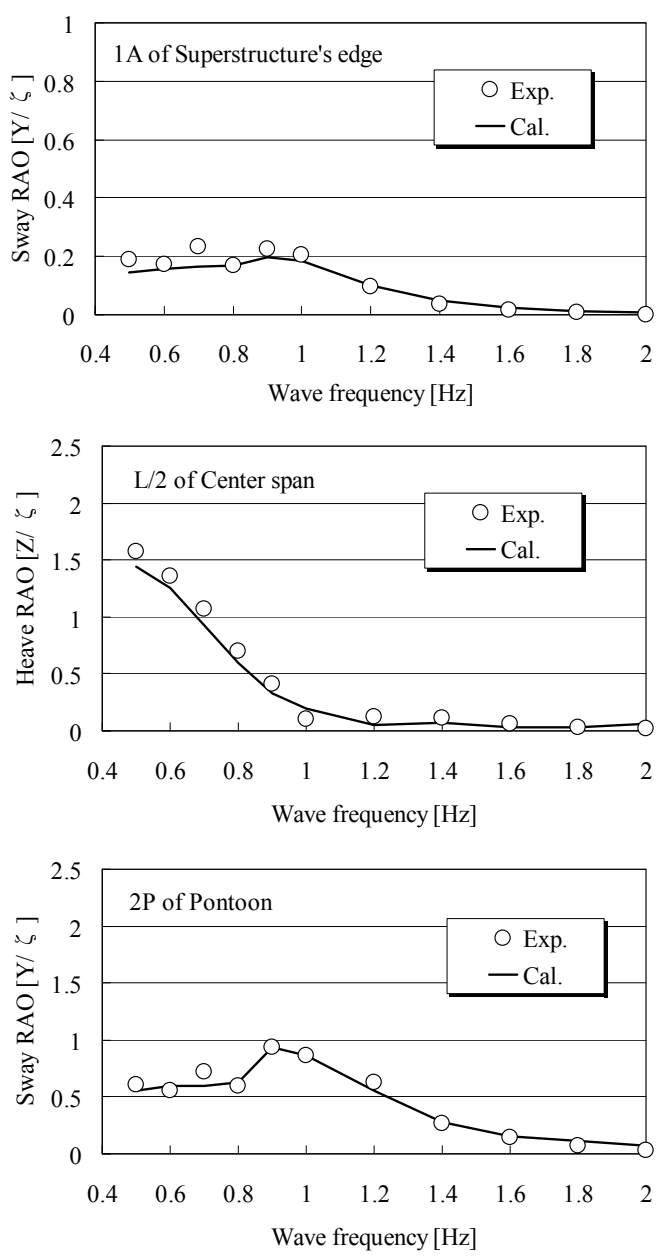

図-24 波向偏角 $\theta=90 \mathrm{deg}$.における運動の周波数応答関数

が推側できる.

鋁直および回転（ねじれ）応答の位相に関しては，2P と1Aおよび3Pと4Aはそれぞれほぼ180deg.の位相差を生 じている.これはポンツーンの動摇が橋脚を介して桁の 振動として伝達される際に時間遅れが生じ, 桁とポンツ ーンの挙動には位相差となって現れると共に，2つのポ ンツーンの動摇は逆位相の関係から，2Pと1Aおよび3P と4Aの位相差も逆位相の関係になったと推測される.

また，図-5のような逆対称モードの影響も現れたと考え られる。

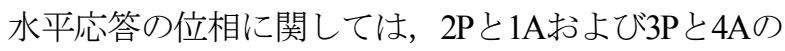
位相差はそれほど生じていない．これは梌の水平方向の 曲げ岡性が強いため, 水平応答については剛体運動に近 かったためと考えられる. また, わずかな位相差が生じ たのは桁の弾性が影響したためと推測される.

図-28 と図-29に，波向偏角 $\theta=75 \mathrm{deg}$. と波向偏角 $\theta$ $=90 \mathrm{deg}$.における入射波の波周波数に対寸る $2 \mathrm{P}$ 側行半長の 各部位の運動の周波数応答関数（実験值）をそれぞれ示 寸. 波向偏角 $\theta=90 \mathrm{deg}$.の場合, 中央径間 $\mathrm{L} / 2$ 点と中央径 間L/4点ともに同等であり, 桁端部1Aは小さい. これは 

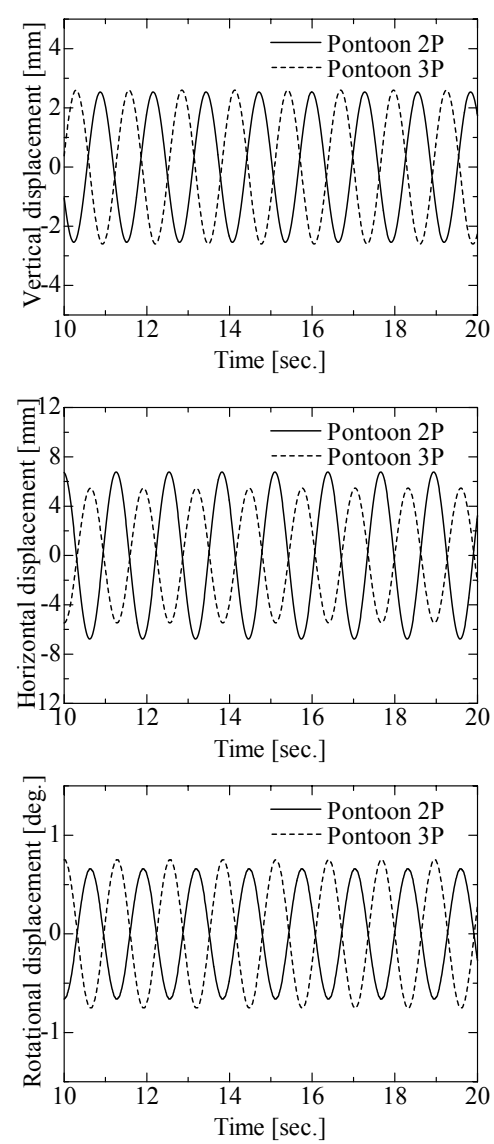

図-25 ポンツーン2Pと3Pの応答時系列（波向偏角 $\theta=75 \mathrm{deg}$.
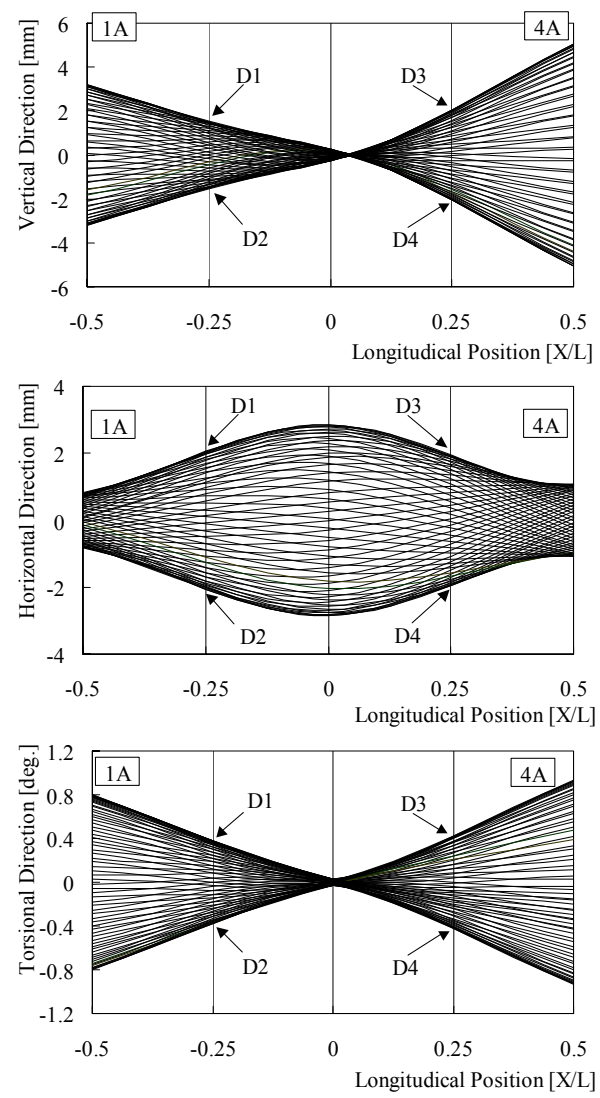

図-27 桁の振動分布（波周波数 $0.8 \mathrm{~Hz}$, 波向偏角 $\theta=75 \mathrm{deg}$.)
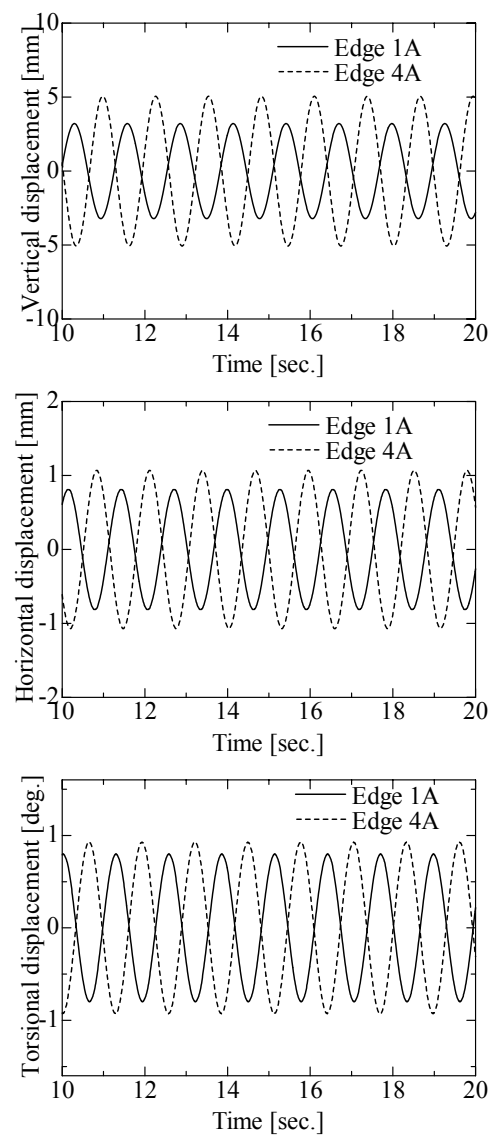

図-26 桁端部1Aと4Aの応答時系列（波向偏角 $\theta=75 \mathrm{deg}$.)

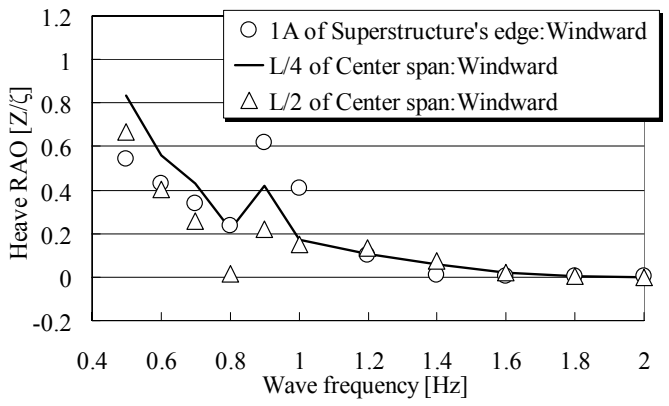

図-28 波向偏角 $\theta=75 \mathrm{deg}$.における2P側桁半長の各部位に 対する運動の周波数応答関数

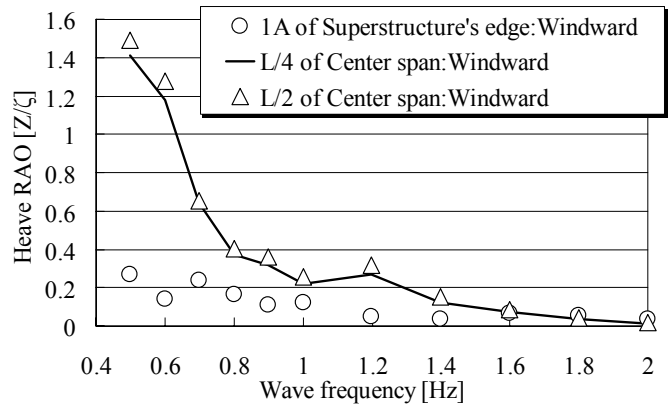

図-29 波向偏角 $\theta=90 \mathrm{deg}$.における2P側析半長の各部位に 対する運動の周波数応答関数 


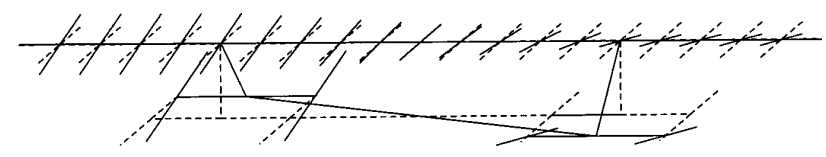

図-30 ポンツーン逆位相運動および析ねじれ逆対称振動

桁が橋軸方向に対して一様に変動し, 端部の值が小さい のは係留の影響であると予測される.

また，波向偏角 $\theta=75 \mathrm{deg}$.の場合，各部位の変動は一様 ではない，これは橋軸方向に対して桁の弾性によるねじ れの影響によるものと推察される.

以上より，入射波の波周波数 $0.8 \mathrm{~Hz}$ に対して，鉛直方 向，水平方向，回転（ねじれ）方向のいずれの系も桁の 弾性影響が生じており，ポンツーン2Pと3Pは，ほぼ 180deg.の位相差を有しながら交互に運動することによっ て，浮体橋全体としては図-30に示すようなポンツーン は逆位相運動を，桁はねじれ逆対称振動を生じたと推察 される.

\section{(4)外力として風と波が同時に作用する場合}

図-13の係留特性から係留力が26.4Nまでは線形領域で あることを表しているが，係留力の両振幅最大值の周波 数応答関数を示寸図-31より，波周波数が $0.4 \mathrm{~Hz} \sim 1.2 \mathrm{~Hz}$ の 範囲内では定反力域の值である26.4Nを越えており，係 留力はその範囲内では非線形領域であることを示してい る.よって，入射波の周波数よっては係留が析全体に非 線形な振動を与える場合もある．また，図より波周波数 が $0.8 \mathrm{~Hz}$ のき，桁端部に作用する係留力のピークが現 れている.

図-32に，偏角 $\theta=90 \mathrm{deg}$.の場合における鉛直方向と水 平方向の応答倍率の周波数応答関数を示す. いずれの系 も波周波数が1.2Hz〜2Hzの範囲内，寸なわち係留特性が 線形領域であるとき，変動風の外力が浮体橋に作用して いる場合でも，規則波の波周期が小さいほど杵とポンツ ーンの各部位の応答倍率は小さくなる傾向がある.

図-33と図-34に，3タイプのそれぞれの外力に対する 中央径間 $\mathrm{L} 2$ 点での水平応答の生值を示す。ここで，変 動風は風洞風速 $8.5 \mathrm{~m} / \mathrm{s}$ のとで，規則波はそれぞれ長周 期側である波周波数 $0.5 \mathrm{~Hz}$ から短周期側である波周波数 2.0Hzまでの実験ケースである.

水平方向に関して, 図-33と図-34より, 風単独で作用 する場合，桁は風下側に定常変位していることを表して いるが，波単独で作用する場合は風下側への定常変位を 示さず，椼は規則波の周期で応答している．よって，風 と波が同時に作用寸る場合，桁が風によって風下側に定 常変位し，その状態で波によって水平応答しているもの と推察される。また，風と波が同時に作用寸る場合，桁

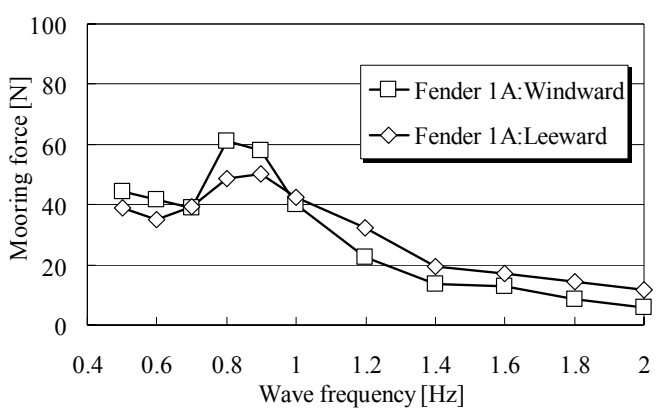

図-31 係留力の両振幅最大值（偏角 $\theta=90 \mathrm{deg}$.)
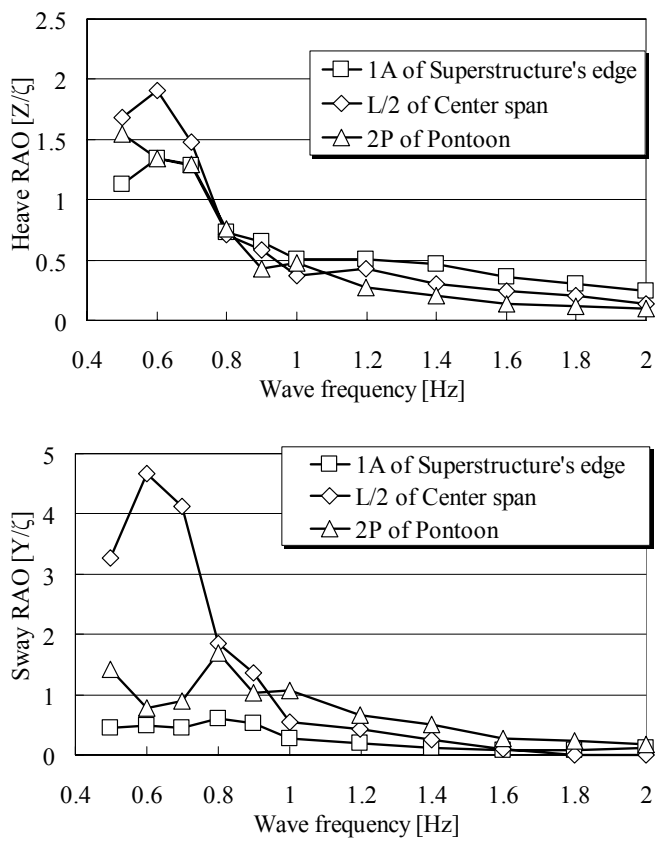

図-32 運動の周波数応答関数（偏角 $\theta=90 \mathrm{deg}$.)

中央径間 $\mathrm{L} 2$ 点の水平方向の振動応答は，不規則的に振 動していることから，短周期側を表す $2.0 \mathrm{~Hz} の 入$ 射規則 波の影響よりも変動風の影響が大きいこと，および長周 期側を表す $0.5 \mathrm{~Hz}$ から $1.2 \mathrm{~Hz}$ の入射規則波に対しては，変 動風の影響で応答の振幅は不規則的ではあるが応答の位 相については入射規則波の周期とほぼ同様であり，波の 影響の方が大きいこと，が推察される.

よって, 本実験で使用した供試模型の矩形断面形状の 桁において水平方向に関しては，風と波が同時に作用す る場合には，ほぼ風の夕による応答と波の夕による応答 との重祆合わせた結果となっていることが分かる.

鉛直方向と回転（ねじれ）方向に関して，図-35と図36 に, 偏角 $\theta=75 \mathrm{deg}$., 風洞風速 $8.5 \mathrm{~m} / \mathrm{s}$, 波周波数 $0.8 \mathrm{~Hz}$ の

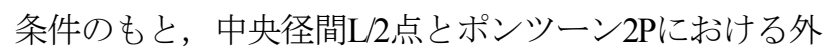
力3タイプのそれぞれに対する鉛直方向および行のねじ れ方向とポンツーンの回転方向の応答時系列をFFT解析 した結果を示す.

図-35と図-36より，鉛直方向，桁のねじれ方向およ 

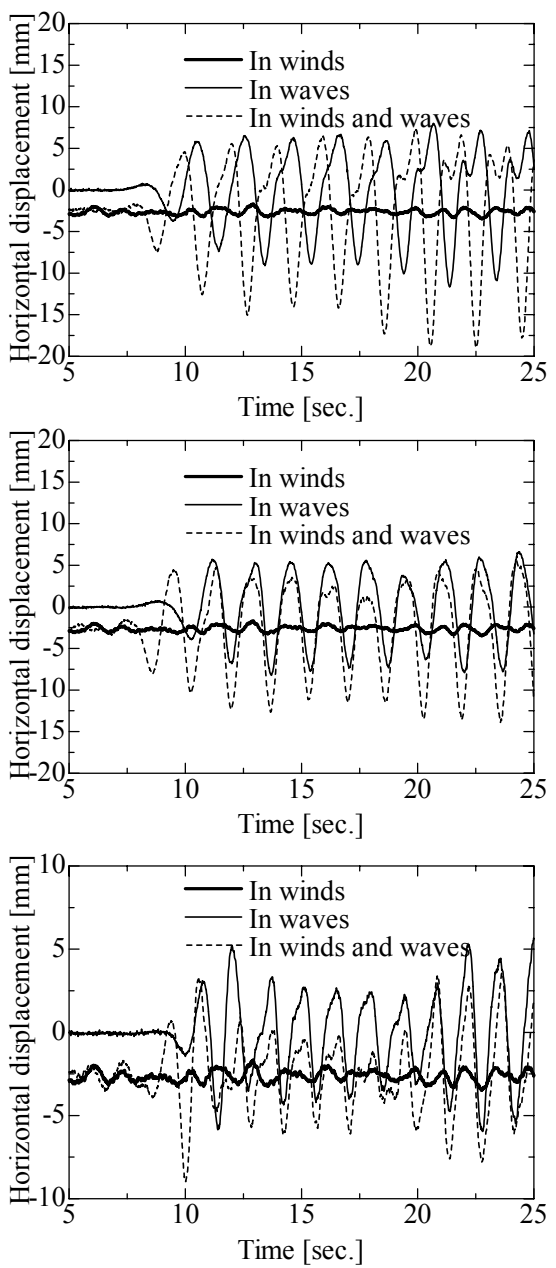

図-33 中央径間 $\mathrm{L} / 2$ 点の応答時系列

（偏角 $\theta=90 \mathrm{deg} .$, 風洞風速 $8.5 \mathrm{~m} / \mathrm{s}$ )

（上から順に，波周波数 $0.5 \mathrm{~Hz}, 0.6 \mathrm{~Hz}, 0.7 \mathrm{~Hz} の$ case）

びポンツーンの回転方向ともに，波が単独で作用する場 合，風と波が同時に作用する場合のそれぞれにおいて， 周波数が $0.8 \mathrm{~Hz}$ 付近で応答振幅のピークが現れる.

図-35では，ねじれ方向について，風が作用する場合 には周波数が $4.2 \mathrm{~Hz}$ 付近で応答振幅のピークが現れる.

これらは，図-4で示されるように，ポンツーンのHeave の固有振動数にほぼ対応していると同時に，桁のねじれ 対称1次モードの固有振動数にもほぼ一致していること による．また，波が単独で作用する場合の応答ピーク值 は風と波が同時に作用する場合の応答ピーク值より2割 程度小さい.

すなわち浮体橋の桁の応答ピーク值について，風によ る影響は2割程度と推察される。

図-36では，波が単独で作用する場合，風と波が同時 に作用する場合において，いずれも振幅はほぼ合致して いる. これは浮体橋が波周波数 $0.8 \mathrm{~Hz}$ の入射波を受ける 場合，ポンツーンの鉛直変位および回転変位に関しては ほとんど風の影響を受けていないと推察される.
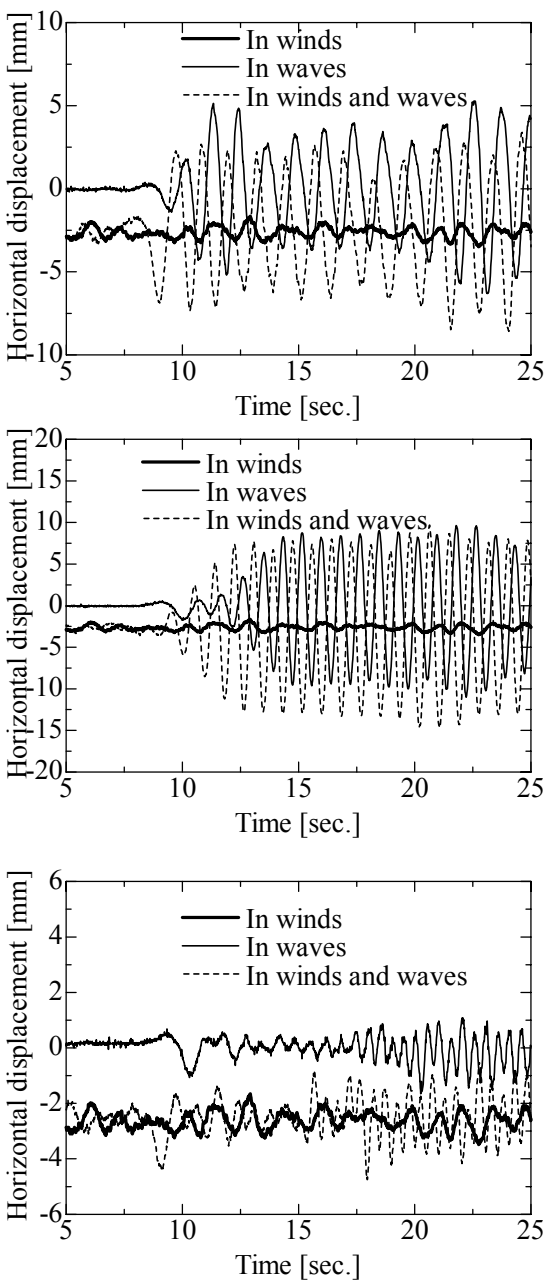

図-34 中央径間 $\mathrm{L} / 2$ 点の応答時系列

（偏角 $\theta=90 \mathrm{deg}$., 風洞風速 $8.5 \mathrm{~m} / \mathrm{s}$ )

（上から順に，波周波数 $0.8 \mathrm{~Hz}, 1.2 \mathrm{~Hz}, 2.0 \mathrm{~Hz} の$ case）

図-37は外力として風と波が同時に作用する場合の桁 各部である1A， L/2，4Aの時刻毎の振動変位から各点の 間の変位值を補間して求めた橋軸方向の桁の振動分布を 示す. ここで， $\mathrm{X} / \mathrm{L}=-0.25$ の位置はポンツーン $2 \mathrm{P} の$ 設置位 置を, $\mathrm{X} / \mathrm{L}=0.25$ の位置はポンツーン3Pの設置位置を表し ている. 外力として波が単独で作用する場合の桁の振動 分布を表す図-27と比較すると, 鉛直方向に関しては, 桁端部1Aと4Aは共に小さいが，中央径間L/2点は大きく， 回転（ねじれ）方向に関しても，桁端部1Aと4Aは共に 若干小さく，中央径間L/2点は大きくなっている。また， 中央径間 $\mathrm{L} / 2$ 点 $(\mathrm{X} / \mathrm{L}=0.25)$ を中心に $0.3 \mathrm{deg}$. 程度の幅を保 持しながらねじれ方向に振動し，3P側上部の桁位置付近 $(\mathrm{X} / \mathrm{L}=0.2)$ を中心に $0.4 \mathrm{~mm}$ 程度の幅を保持しながら鉛直 方向に振動している様子を表している. これは，図-27 の波が単独で作用した場合の様子と違い，風の影響によ って桁端部の応答は抑えられ，中央径間の応答は促進さ れたことで生じた振動モードである.

以上より，外力として波のみが作用する場合を想定す 

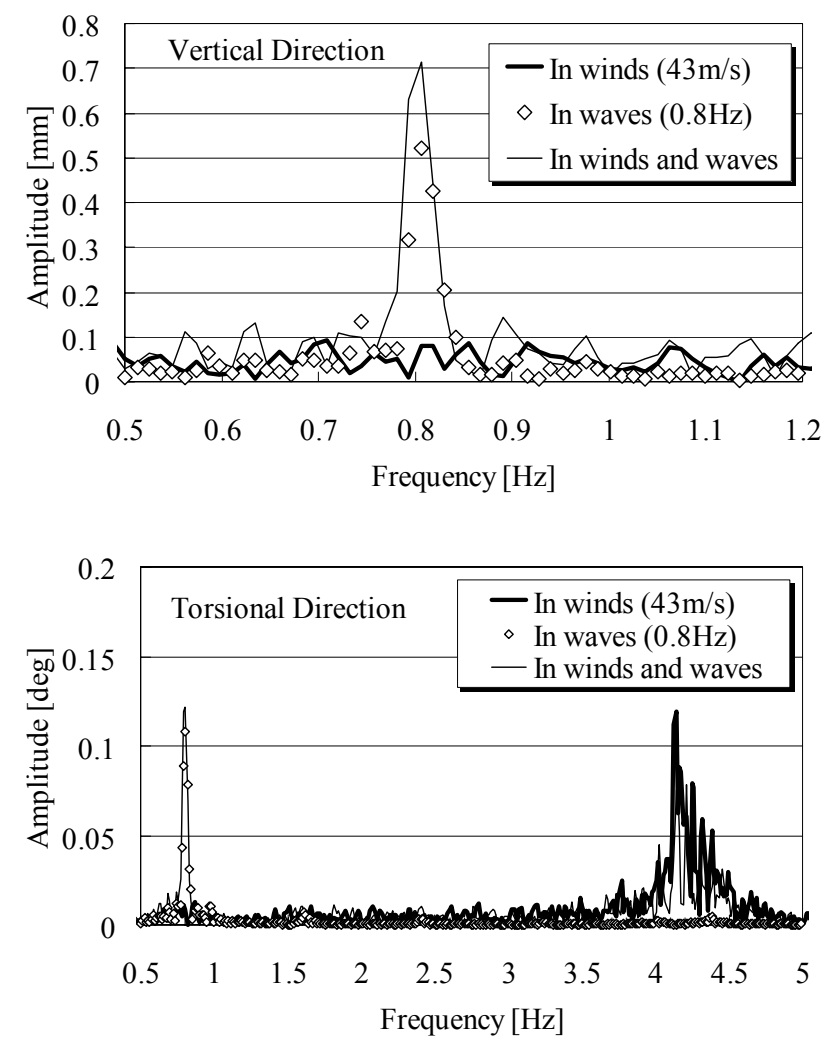

図-35 中央径間 $\mathrm{L} / 2$ 点の応答に対する周波数毎のフーリエ振幅 (偏角 $\theta=75$ deg.)
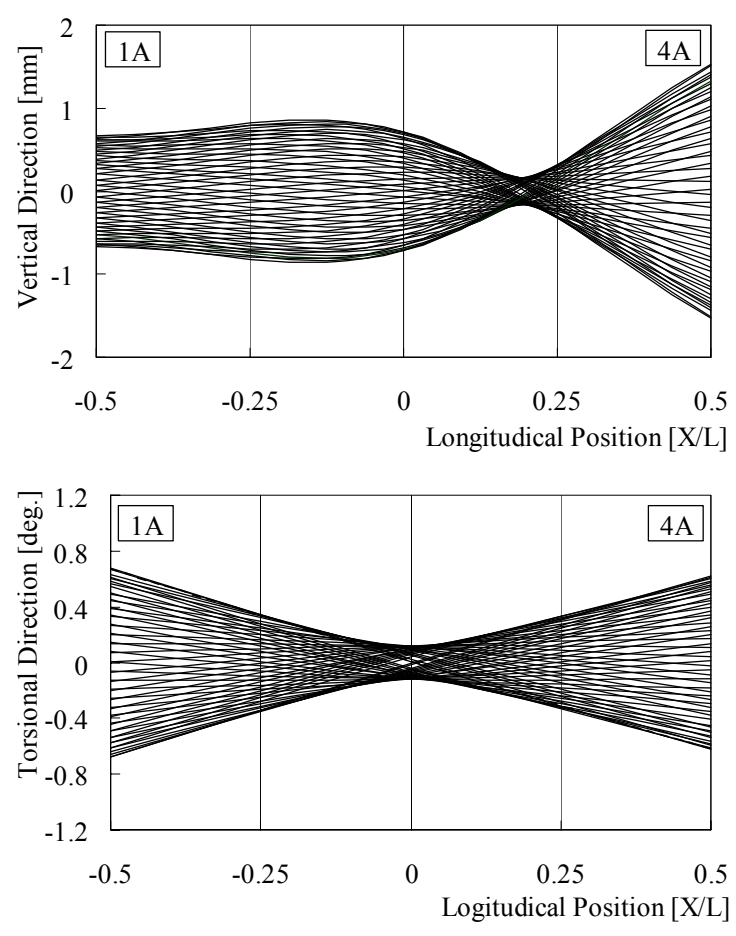

図-37 桁の振動分布（波周波数 $0.8 \mathrm{~Hz}$, 波向偏角 $\theta=75 \mathrm{deg}$.，風洞風速 $8.5 \mathrm{~m} / \mathrm{s}$ )

るだけでなく風と波を同時に受けた場合を想定して，桁 の設計を行う必要がある。
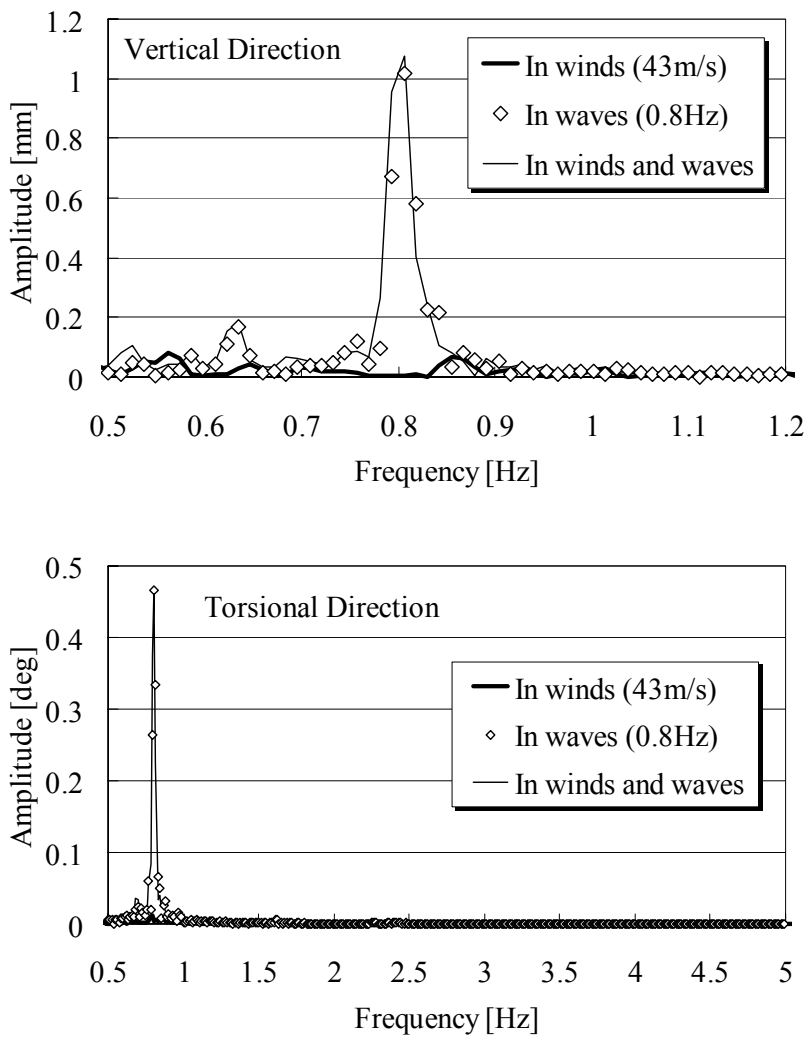

図-36 ポンツーン2Pの応答に対する周波数毎のフーリエ振幅 (偏角 $\theta=75$ deg.)

\section{5. 結 語}

本研究では，風洞設備の風路上に造波装置及び消波装 置を備えた造波水槽を設置し，2車線を有する自動車専 用道路用の 7 径間連続鋼床版箱桁橋の中央部を対象とし た浮体橋弾性模型を浮かべて係留し，これに外力として， 風が単独で作用する場合, 波が単独で作用する場合, 風 と波が同時に作用する場合のそれぞれについて，2種類 の偏角 (橋直方向，橋斜方向)に対する動摇実験を実施し, 分離ポンツーン型浮体橋の弾性応答に及ぼす風と波の影 響を調べた.この結果，以下の知見を得ることができた。 （1）風と波が同時に作用する場合，風の影響によって浮 体橋は風下側に定常変位し，この変位した状態で波の 影響によって動摇することが確認された.

（2）本実験条件において，桁が矩形断面形状の分離ポン ツーン型浮体橋に関しては，風と波を同時に受ける場 合の桁の応答ピーク值は，波が単独で作用する場合より も2割程度大きいことが確認された。

（3）入射波が偏角を有するとき，浮体橋の固有振動数に 対応する波周波数に対して，鈆直方向，水平方向，回 転(ねじれ)方向のいずれの系も桁の弾性影響が生じや すく，2つのポンツーンの応答は，逆位相で交互に同 
振幅し，桁はねじれの逆対称モードが生じることが確 認された. しかし，桁およびポンツーンの形状変更に よりそれらの構造の間に相互干渉の生じることも予見 されるため, 今後, 実験の積み重ねが必要である.

(4) 風洞内水槽実験の波浪中弾性挙動は, 麓ら ${ }^{14)}$ による 解析手法で得られた結果とほぼ一致しており, 本稿で 実施された実験手法は妥当なものと判断された。

今回の実験的検証においては，変動風と規則波を同時 に受ける弾性浮体橋の実験方法を確立することであった が，今後，実海域を想定すると，変動風と不規則波が同 時に作用するような検証が望まれる。 また，風の乱れの 変化が挙動に及ぼす影響およびポンツーンと枌の相互に 干渉する影響を精査することも今後の課題である.

なお本論文は，(独）士木研究所，京都大学，日立造船 (株)，新日本製鐵(株)，(株)建設技術研究所による共同 研究「浮体橋の波浪・風作用下での動摇解析手法の開 発」で実施した結果を一部含んだものになっている.

\section{参考文献}

1) 丸山忠明 : 旋回式浮体橋の建設, 第14回海洋工学シンポジウ ム, pp.327-334, 1998.

2) 土木学会鋼構造委員会浮体橋の研究小委員会 : 浮体橋の設計 指針, 土木学会, 2006.

3) 丸山忠明, 川村幸男, 武田純男, 永田修一, 三宅成司郎, 藤 田孝 : 浮体式橋梁の波浪中動摇に関する水理実験, 海岸工学 論文集，Vol.44，pp.896-900， 1997.

4) 永田修一, 三宅成司郎, 藤田孝, 吉田尚史, 武田純男, 丸山 忠明, 上田茂 : 旋回式浮体橋の波浪中動摇実験, 第14回海洋 工学シンポジウム, pp.335-342, 1998.

5) 小林正典, 日根野元裕, 島田潔, 兵頭孝司, 河本淳, 上田茂, 丸山忠明 : 旋回式浮体橋の波浪中旋回試験, 第14回海洋工学 シンポジウム, pp.351-358, 1998.

6)池上国広, 今泉好照, 井上幸一, 岡俊蔵, 上田茂, 丸山忠
明 : 旋回式浮体橋の波浪中弾性応答水槽試験, 第14回海洋工 学シンポジウム, pp.343-350, 1998.

7) 上田茂, 丸山忠明, 熊本直樹, 井上幸一, 池上国広 : 弾性体 模型を用いた浮体橋の波浪応答実験, 土木学会第53回年次学 術講演会講演概要集, pp.368-369, 1998.

8) 岡俊蔵, 熊本直樹, 井上幸一, 池上国広, 瀬戸秀幸, 上田茂, 丸山忠明 : 浮体橋梁の波浪に対する弾性応答解析法の開発, 三菱重工技報, Vol.36, No.5, pp.234-237, 1999 .

9) 村越潤, 麓興一郎, 永田修一, 田中 洋, 渡邊英一, 宇都宮 智昭, 新里英幸, 白井秀治 : 風・波作用下にある浮体橋の弾 性挙動に関する模型実験, 日立造船技報, 第64巻, 第2号, 2003.

10) 村越潤, 麓興一郎, 永田修一, 新里英幸, 白井秀治, 渡邊 英一, 宇都宮智昭 : 波と風の複合外力下における浮体橋の弾 性挙動に関する実験的研究, 構造工学論文集, Vol.50A, pp.613-622, 2004.

11) 上田茂, 白石悟, 丸山忠明, 上薗晃, 高崎守, 山瀬晴義 : 浮体橋に使用する係留用ゴムフェンダーの特性, 第14回海洋 工学シンポジウム, pp.359-364, 1998.

12) 渡邊英一, 宇都宮智昭, 岡藤孝史, 村越潤, 麓興一郎 : 浮 体橋の波浪応答シミュレーションプログラムの開発, 構造工 学論文集, Vol.49A,pp.661-668, 2003.

13) Murakoshi, J., Fumoto, K., Nagata, S., Niizato, H., Tanaka, H., Watanabe, E. and Utsunomiya, T.: Experimental Study on Motions of an Elastic Floating Bridge in Waves and Winds, Proc.of 3rd International Conference on Advances in Structural Engineering and Mechanics, CD-ROM, 2004.

14) 麓興一郎, 宇都宮智昭, 新里英幸, 田中 洋, 渡邊英一 : 風・波を同時に受ける浮体橋の動的応答シミュレーションプ ログラムの開発，土木学会論文集A，Vol.62，No.4，pp.729739, 2006.

15) 日本造船学会海洋工学委員会性能部会編 : 浮体の流体力学 後編, pp.221-245, 成山堂, 2003.

(2006.5.9受付)

\title{
EXPERIMENT ON MOTIONS OF ELASTIC FLOATING BRIDGE IN WINDS AND WAVES
}

\section{Koichiro FUMOTO, Hideyuki NIIZATO, Tomoaki UTSUNOMIYA, Hiroshi TANAKA and Eiichi WATANABE}

\begin{abstract}
This paper deals with experiment of the dynamic motion of an elastic floating bridge in winds and waves using a wave generator tank installed in a wind tunnel. The ends of the superstructure are moored by mooring devices with nonlinear restoring force characteristics in the horizontal direction transverse to the bridge axis. From the experiments, it is found that the dynamic motion of the floating bridge may be affected more strongly by the wave force than by the wind force. Moreover, the floating bridge is moved to the leeward side by the wind force and the dynamic motion by the wave force is done in the place after it moves. The analytical results with the computer program by the authors (Fumoto et al.,2006) for the dynamic elastic behavior of the floating bridge in waves are found to have good correlations with the experimental ones.
\end{abstract}

